\title{
SOLID STATE ENERGY CONVERSION ALLIANCE (SECA) \\ SOLID OXIDE FUEL CELL PROGRAM
}

\author{
Semi-Annual Report \\ October 2001 - March 2002 \\ Submitted June 2003 \\ DE-FC26-01NT41245
}

\author{
Honeywell \\ Airframe Systems \\ 2525 West $190^{\text {th }}$ Street \\ Torrance, CA 90504 \\ Submitted to \\ United States Department of Energy \\ National Energy Technology Laboratory \\ Pittsburgh, PA
}




\section{Disclaimer}

"This report was prepared as an account of work sponsored by an agency of the United States Government. Neither the United States Government nor any agency thereof, nor any of their employees, makes any warranty, expressed or implied, or assumes any legal liability or responsibility for the accuracy, completeness, or usefulness of any information, apparatus, product, or process disclosed, or represents that its use would not infringe privately owned rights. Reference herein to any specific commercial product, process, or service by trade name, trademark, manufacturer, or otherwise, does not necessarily constitute or imply its endorsement, recommendation, or favoring by the United States Government or any agency thereof. The views and opinions of authors expressed herein do not necessarily state or reflect those of the United States Government or any agency thereof." 


\begin{abstract}
This report summarizes the progress made during the September 2001-March 2002 reporting period under Cooperative Agreement DE-FC26-01NT41245 for the U. S. Department of Energy, National Energy Technology Laboratory (DOE/NETL) entitled "Solid State Energy Conversion Alliance (SECA) Solid Oxide Fuel Cell Program". The program focuses on the development of a low-cost, high-performance 3-to-10-kW solid oxide fuel cell (SOFC) system suitable for a broad spectrum of power-generation applications. The overall objective of the program is to demonstrate a modular SOFC system that can be configured to create highly efficient, cost-competitive, and environmentally benign power plants tailored to specific markets. When fully developed, the system will meet the efficiency, performance, life, and cost goals for future commercial power plants.
\end{abstract}




\section{Table of Contents}

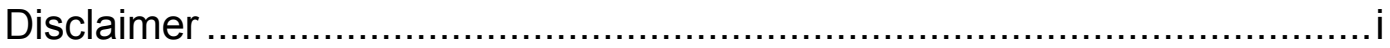

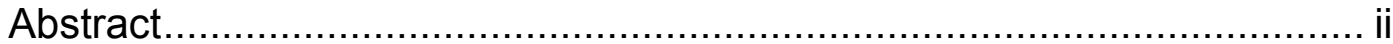

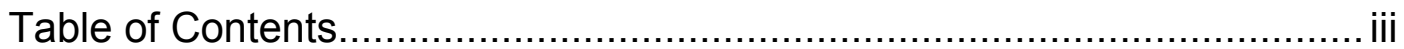

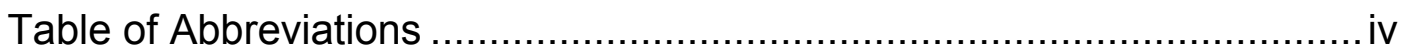

Executive Summary ................................................................... 1

Experimental (Approach), Results and Discussion ............................ 3

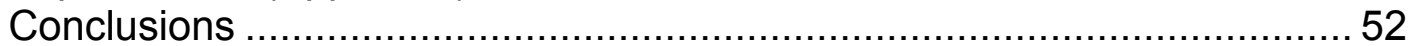

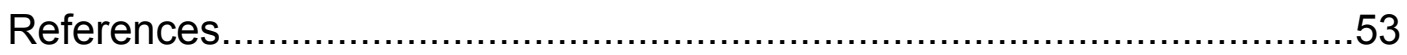

Appendix (Protected EPACT Information)...................Published Separately 
$\underline{\text { Table of Abbreviations }}$

$\begin{array}{ll}\text { ASR: } & \text { Area Specific Resistance } \\ \text { ATR: } & \text { Autothermal Reforming } \\ \text { BOM: } & \text { Bill of Materials } \\ \text { BOP: } & \text { Balance of Plant } \\ \text { CPOX: } & \text { Catalytic Partial Oxidation } \\ \text { CSD: } & \text { Conceptual System Design } \\ \text { CTQ: } & \text { Critical to Quality } \\ \text { DFSS: } & \text { Design for Six Sigma } \\ \text { DOE: } & \text { United States Department of Energy } \\ \text { EPOX: } & \text { Electrochemical Partial Oxidation } \\ \text { FMEA: } & \text { Failure Mode and Effects Analysis } \\ \text { LSM: } & \text { Lanthanum Strontium Manganite } \\ \text { NETL: } & \text { DOE National Energy Technology Laboratory } \\ \text { OCV: } & \text { Open Circuit Voltage } \\ \text { PID: } & \text { Proportional-Integral-Derivative Control } \\ \text { QFD: } & \text { Quality Function Deployment } \\ \text { SEM: } & \text { Scanning Electron Microscope } \\ \text { SOFC: } & \text { Solid Oxide Fuel Cell } \\ \text { TEM: } & \text { Transmission Electron Microscope } \\ \text { YSZ: } & \text { Yttria-stabilized Zirconia }\end{array}$




\section{Executive Summary}

This report summarizes the progress made during the September 2001March 2002 reporting period under Cooperative Agreement DE-FC2601 NT41245 for the U. S. Department of Energy, National Energy Technology Laboratory (DOE/NETL) entitled "Solid State Energy Conversion Alliance (SECA) Solid Oxide Fuel Cell Program". The program focuses on the development of a low-cost, high-performance 3-to-10-kW solid oxide fuel cell (SOFC) system suitable for a broad spectrum of power-generation applications. The overall objective of the program is to demonstrate a modular SOFC system that can be configured to create highly efficient, cost-competitive, and environmentally benign power plants tailored to specific markets. When fully developed, the system will meet the efficiency, performance, life, and cost goals for future commercial power plants.

Highlights of activities from this reporting period include:

- System Analysis: Stack and system models have been developed to predict stack performance and system flows, efficiencies and outputs.

- Cost Estimate: The cost model was updated and component estimates were refined.

- Stack Technology Development

- Stack Design Evaluation: Preliminary stack requirements were defined, and key technology gaps identified.

- Materials Evaluation and Optimization: Cell performance gap identified, oxidation estimate of interconnect material performed, and work initiated on improved anode porosity.

- Thermal Cycling: Stack thermal cycling Failure Mode and Effect Analysis (FMEA) was conducted, and past data was analyzed to determine technology gaps.

- Stack Lifetime: Experiments were performed to isolate the controlling mechanism of degradation within the stack.

- Performance Evaluation and Improvement: Single cell and stack assembly and testing procedures for the program were developed and implemented, gas flow tube pressure drops were analyzed for large footprint stacks.

- Stack Fabrication and Processing: Cell fabrication process flow documents were created and work was started to evaluate fabrication of larger footprint cells.

- Fuel Processing: A fuel processing technology assessment was completed and is summarized, fuel processor technology gaps were studied, and work was done to fabricate an improved fuel processing test stand. 
- Control and Sensor Development: A dynamic system model of the SECA conceptual system was assembled and is being debugged and verified.

- Thermal Management Subsystem: A novel recuperator design was developed and analyzed, material evaluation is underway, and a experimental setup is being developed. 


\section{INTRODUCTION}

\section{Experimental (Approach), Results and Discussion}

This report summarizes the progress made during the September 2001March 2002 reporting period under Cooperative Agreement DE-FC2601 NT41245 for the U. S. Department of Energy, National Energy Technology Laboratory (DOE/NETL) entitled "Solid State Energy Conversion Alliance (SECA) Solid Oxide Fuel Cell Program". The program focuses on the development of a low-cost, high-performance 3-to-10-kW solid oxide fuel cell (SOFC) system suitable for a broad spectrum of power-generation applications. The overall objective of the program is to demonstrate a modular SOFC system that can be configured to create highly efficient, cost-competitive, and environmentally benign power plants tailored to specific markets. When fully developed, the system will meet the efficiency, performance, life, and cost goals for future commercial power plants.

\section{OVERVIEW}

The concept SOFC system is a power module ( 3 to $10 \mathrm{~kW}$ ) capable of operating on a variety of fuels. The system consists of all the required components for a self-contained unit, including fuel cell stack, fuel processing subsystem, fuel and oxidant delivery subsystem, thermal management subsystem, and various control and regulating devices. The proposed system is also designed to be modular and can be integrated to form a larger system. Figure 1 shows an example of the proposed system concept.

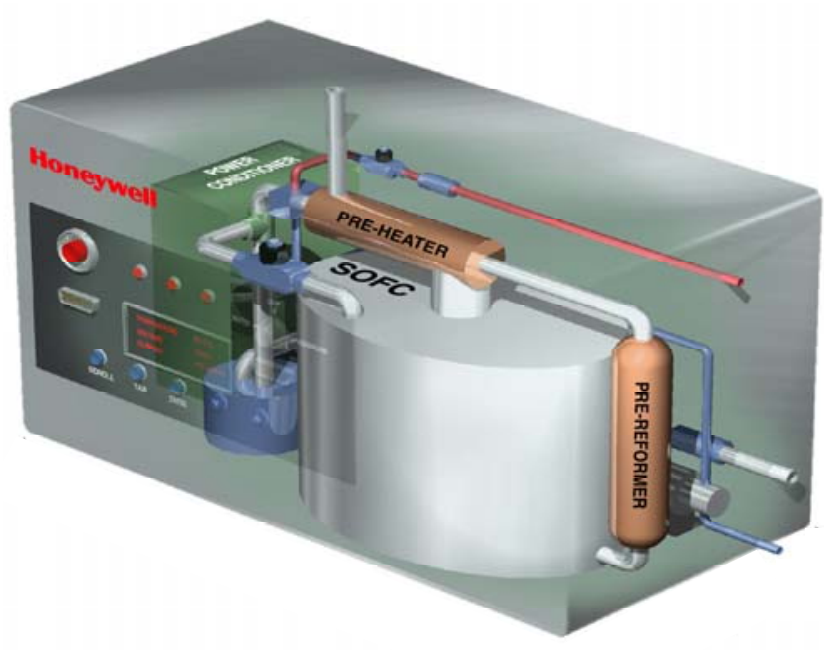

Figure 1. SECA System Concept 
The key components include a low-cost, lightweight SOFC and a compact, fuel flexible fuel processor, along with thermal management and advanced control subsystems:

- The concept SOFC is a compact stack of thin-electrolyte cells (fabricated by tape calendaring) and thin foil metallic interconnects. The stack design is based on an advanced concept that maximizes cell active area and minimizes sealing. The proposed fuel cell can operate directly on light hydrocarbon fuels (such as natural gas) and incorporates materials for high performance at reduced temperatures $\left(<800^{\circ} \mathrm{C}\right)$. These characteristics provide a low-cost, fuel-flexible fuel cell suitable for operation under various conditions without significant redesign or modification of the system. The tape calendaring process for manufacturing thin-electrolyte cells is a potentially low-cost, masscustomization technique suitable for high-volume production and automation using commercial equipment.

- The fuel processor is a catalytic reactor that functions as a prereformer. For the baseline design, the prereformer can be operated as catalytic partial oxidation (CPOX) or autothermal reforming (ATR) for processing different fuels. These characteristics permit a lightweight, compact, fuel-flexible fuel processor design, resulting in smaller system size and lower cost.

- The concept system employs an integrated thermal management approach to utilize by-product heat and reduce heat losses, and consequently, increase the overall system efficiency. The system also has a flexible control structure that can be modified or optimized for different applications.

The general features of the SECA SOFC program are summarized in Figure 2. The Phase I will culminate in a demonstration of a modular SOFC system suitable for operation under different conditions. A specified application will be selected at the beginning of Phase II. Phase II will result in a demonstration of a packages system for the specified application. Phase III will result in field testing of a packaged system for the specified application for extended periods to demonstrate operating characteristics required for commercial power plants. 


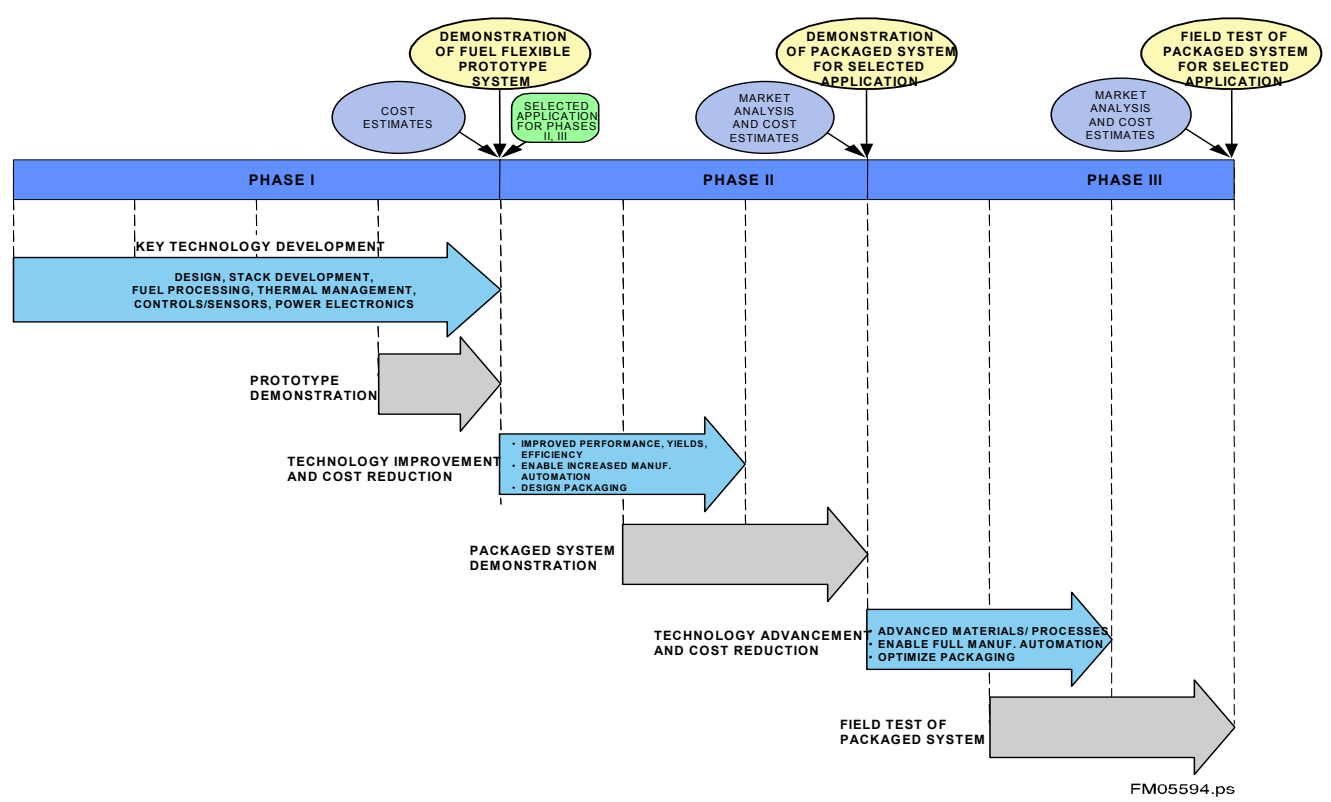

Figure 2. Key Program Features

\section{SYSTEM ANALYSIS}

The system analysis effort (Task 1.1) consists of the following subtasks:

- Task 1.1.1 System Definition and Analysis

- Task 1.1.2 Parametric Studies

- Task 1.1.3 Prototype System Development.

As subtasks 1.1.2 and 1.1.3 are not scheduled to start until late 2002 and 2003, respectively, this report will only be concerned with Task 1.1.1, System Definition and Analysis.

Tasks within System Definition and Analysis include System Requirements Definition, Preliminary Analysis, Stack Model Development, System Model Development, and System Concept Definition.

Figure 3 illustrates the procedure that will be utilized in Phase I to define a conceptual system design (CSD) to meet the Phase III requirements. The process inputs include the system requirements and technology data. The major outputs include the CSD and identified technology gaps between the system requirements and current capabilities. The process is iterative, starting with Conceptual System Design version 0 (CSDv0) which was effectively the system given in the Honeywell proposal to $\mathrm{DOE}^{1}$. There are three iterations planned from the proposal (i.e., v1, v2, and v3), leading to the finalized CSD for the specified application.

\footnotetext{
${ }^{1}$ Solid State Energy Conversion Alliance - Solid Oxide Fuel Cell Program, Proposal to DOE, 1/24/01 (HON 2K-71286-2)
} 


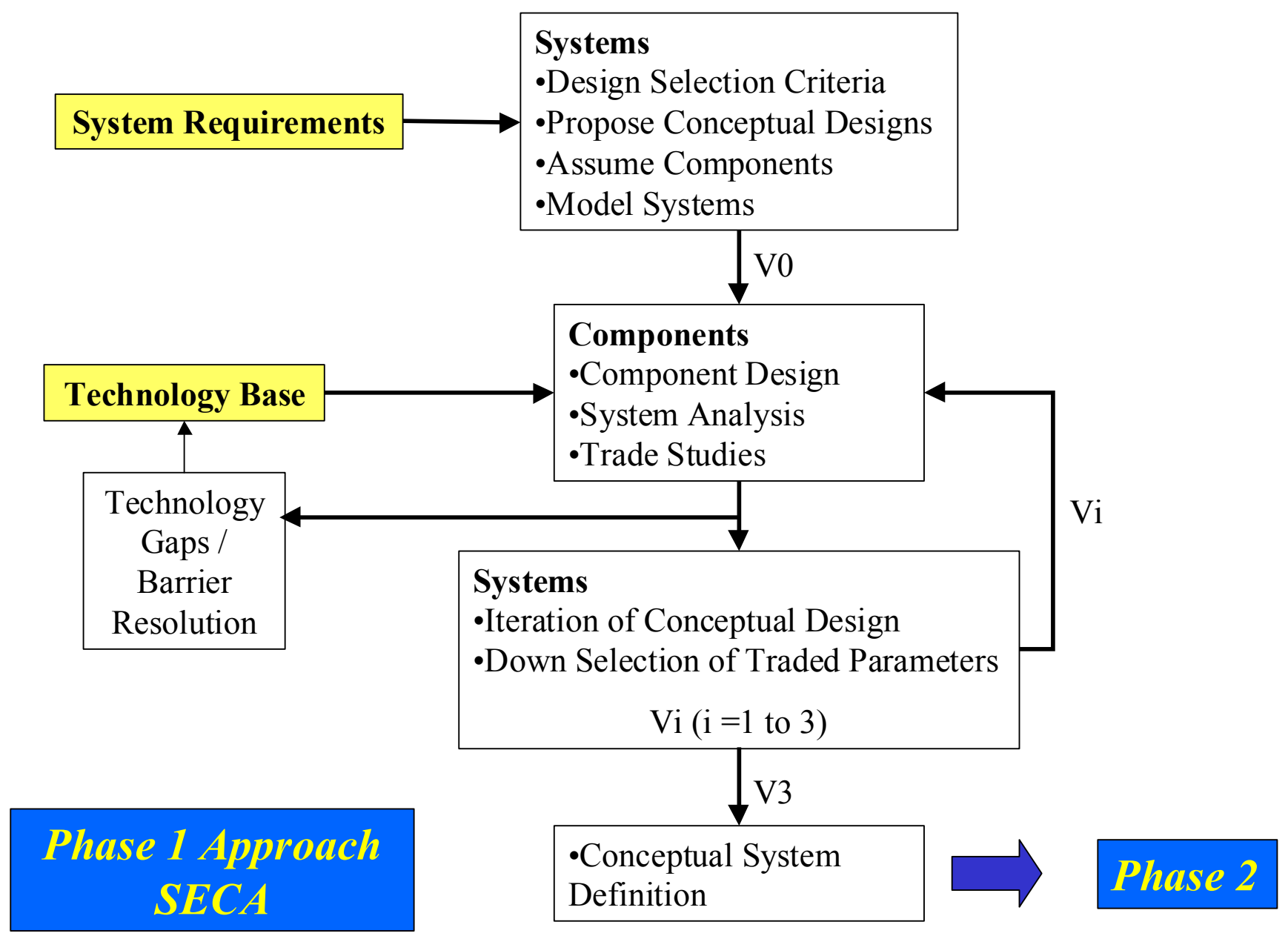

Figure 3. Conceptual System Design Process Map

\subsection{System Requirements Definition}

The DOE's minimum requirements are summarized in Table 1. The system performance analysis effort that is being undertaken is intended to develop a conceptual system design based on the use of the Phase III requirements. The use of these program targets in the development of the conceptual system design will allow the early identification of programmatic risks in the selection of the system components.

Table 1. DOE Minimum System Requirements

\begin{tabular}{|l|l|l|l|}
\hline & \multicolumn{1}{|c|}{ PHASE I } & \multicolumn{1}{c|}{ PHASE II } & \multicolumn{1}{c|}{ PHASE III } \\
\hline $\begin{array}{l}\text { POWER RATING } \\
\text { (NET) }\end{array}$ & $3 \mathrm{~kW}-10 \mathrm{~kW}$ & $3 \mathrm{~kW}-10 \mathrm{~kW}$ & $3 \mathrm{~kW}-10 \mathrm{~kW}$ \\
\hline COST & $\$ 800 / \mathrm{kW}$ & $\$ 600 / \mathrm{kW}$ & $\$ 400 / \mathrm{kW}$ \\
\hline $\begin{array}{l}\text { EFFICIENCY (AC } \\
\text { or DC/LHV) }\end{array}$ & $\begin{array}{l}\text { Mobile - 25\% } \\
\text { Stationary -35\% }\end{array}$ & $\begin{array}{l}\text { Mobile - 30\% } \\
\text { Stationary - 40\% }\end{array}$ & $\begin{array}{l}\text { Mobile - 30\% } \\
\text { Stationary - } 40 \%\end{array}$ \\
\hline STEADY STATE & 1500 hours & 1500 hours & 1500 hours \\
\hline
\end{tabular}




\begin{tabular}{|c|c|c|c|}
\hline $\begin{array}{l}\text { TEST @ NORMAL } \\
\text { OPERATING } \\
\text { CONDITIONS }\end{array}$ & $\begin{array}{l}80 \% \text { availability } \\
\Delta \text { Power }=2 \% \text { degradation } \\
/ 500 \text { hours at a constant } \\
\text { stack voltage with } R \text { R } 0.95 \text {. } \\
\text { R-Linear Correlation } \\
\text { Coefficient }\end{array}$ & $\begin{array}{l}85 \% \text { availability } \\
\Delta \text { Power }=1 \% \text { degradation } \\
/ 500 \text { hours at a constant } \\
\text { stack voltage with } R \text { _ } 0.95 \text {. } \\
\text { R-Linear Correlation } \\
\text { Coefficient }\end{array}$ & $\begin{array}{l}95 \% \text { availability } \\
\Delta \text { Power }=0.1 \% \text { degradation } \\
\text { /500 hours at a constant } \\
\text { stack voltage with } R \text { R } 0.95 . \\
\text { R-Linear Correlation } \\
\text { Coefficient }\end{array}$ \\
\hline TRANSIENT TEST & $\begin{array}{l}10 \text { cycles } \\
\Delta \text { Power }=1 \% \text { degradation } \\
\text { after } 10 \text { cycles at a constant } \\
\text { stack voltage }\end{array}$ & $\begin{array}{l}50 \text { cycles } \\
\Delta \text { Power }=0.5 \% \\
\text { degradation after } 50 \text { cycles } \\
\text { at a constant stack voltage }\end{array}$ & $\begin{array}{l}100 \text { cycles } \\
\Delta \text { Power }=0.1 \% \text { degradation } \\
\text { after } 100 \text { cycles at a } \\
\text { constant stack voltage }\end{array}$ \\
\hline TEST SEQUENCE & $\begin{array}{l}\text { 1) Steady State Test - } \\
1000 \text { hours } \\
\text { 2) Transient Test } \\
\text { 3) Steady State Test - } 500 \\
\text { hours }\end{array}$ & $\begin{array}{l}\text { 1) Steady State Test - } \\
1000 \text { hours } \\
\text { 2) Transient Test } \\
\text { 3) Steady State Test - } \\
500 \text { hours }\end{array}$ & $\begin{array}{l}\text { 1) Steady State Test - } \\
1000 \text { hours } \\
\text { 2) Transient Test } \\
\text { 3) Steady State Test - } 500 \\
\text { hours }\end{array}$ \\
\hline FUEL TYPE & $\begin{array}{l}\text { For the complete duration of } \\
\text { the Steady State and } \\
\text { Transient Tests, operate the } \\
\text { Prototype on either a } \\
\text { commercial commodity, } \\
\text { natural gas, gasoline, or } \\
\text { diesel fuel(s) or a } \\
\text { representative fuel based on } \\
\text { respectively methane, iso- } \\
\text { octane, or hexadecane } \\
\text { corresponding to the } \\
\text { proposed primary } \\
\text { application (s) Utilize } \\
\text { external or internal primary } \\
\text { fuel reformation or oxidation. } \\
\text { If multiple applications using } \\
\text { different fuels are proposed } \\
\text { split the total test time } \\
\text { equally among the different } \\
\text { fuel types. }\end{array}$ & $\begin{array}{l}\text { For the complete duration } \\
\text { of the Steady State and } \\
\text { Transient Tests, operate } \\
\text { the Prototype on either a } \\
\text { commercial commodity, } \\
\text { natural gas, gasoline, or } \\
\text { diesel fuel(s) corresponding } \\
\text { to the proposed primary } \\
\text { application (s) Utilize } \\
\text { external or internal primary } \\
\text { fuel reformation or } \\
\text { oxidation. If multiple } \\
\text { applications using different } \\
\text { fuels are proposed split the } \\
\text { total test time equally } \\
\text { among the different fuel } \\
\text { types. }\end{array}$ & $\begin{array}{l}\text { For the complete duration of } \\
\text { the Steady State and } \\
\text { Transient Tests, operate the } \\
\text { Prototype on either a } \\
\text { commercial commodity, } \\
\text { natural gas, gasoline, or } \\
\text { diesel fuel(s) corresponding } \\
\text { to the proposed primary } \\
\text { application (s) Utilize } \\
\text { external or internal primary } \\
\text { fuel reformation or oxidation. } \\
\text { If multiple applications using } \\
\text { different fuels are proposed } \\
\text { split the total test time } \\
\text { equally among the different } \\
\text { fuel types. }\end{array}$ \\
\hline $\begin{array}{l}\text { MAINTENANCE } \\
\text { INTERVALS }\end{array}$ & $\begin{array}{l}\text { Design aspects should not } \\
\text { require maintenance at } \\
\text { intervals more frequent than } \\
1000 \text { operating hours }\end{array}$ & $\begin{array}{l}\text { Design aspects should not } \\
\text { require maintenance at } \\
\text { intervals more frequent } \\
\text { than } 1000 \text { operating hours }\end{array}$ & $\begin{array}{l}\text { Design aspects should not } \\
\text { require maintenance at } \\
\text { intervals more frequent than } \\
1000 \text { operating hours }\end{array}$ \\
\hline DESIGN LIFETIME & $\begin{array}{l}\text { Not less than } 40,000 \\
\text { operating hours for } \\
\text { stationary applications and } \\
5,000 \text { hours for } \\
\text { transportation applications } \\
\text { for military uses. }\end{array}$ & $\begin{array}{l}\text { Not less than } 40,000 \\
\text { operating hours for } \\
\text { stationary applications and } \\
5,000 \text { hours for } \\
\text { transportation applications } \\
\text { for military uses. }\end{array}$ & $\begin{array}{l}\text { Not less than } 40,000 \\
\text { operating hours for } \\
\text { stationary applications and } \\
5,000 \text { hours for } \\
\text { transportation applications } \\
\text { for military uses. }\end{array}$ \\
\hline
\end{tabular}

However, the goals defined as the requirements for each phase will still be used to validate the effort performed in each phase. In other words, although in this effort, the components are designed to achieve the best overall system performance (highest efficiency, lowest degradation, per Phase III), the targets for Phase I are still the ones listed in this section of the requirements (such as the cost goal of $\$ 800 / \mathrm{kW})$.

From this set of goals, the following more specific requirements have been derived for the Conceptual System Design: 
1) Power rating: $\mathbf{5 k W}$. This was established as the basis power for the program.

2) Cost (for primary application): $\$ \mathbf{8 0 0 / k W}$. Eventually, the cost goal will evolve to $\$ 400 / \mathrm{kW}$ to adjust to the Phase III requirements.

3) Efficiency: 40\%. The natural gas fed stationary application was chosen as the primary application at this stage of the program.

4) Degradation: $\mathbf{0 . 4 \%}$ for $\mathbf{1 5 0 0 - h r}$ test sequence. After transient and steady state tests (a total of 1500 hours at steady state and 100 transient cycle tests), the system will produce a minimum of $5 \mathrm{~kW}$ at a minimum of 40 $\%$ efficiency on natural gas while degrading a maximum of $0.4 \%$ of the initial net power output.

5) Fuels: Natural gas for the primary application. The way to adapt to other fuels (such as diesel or gasoline) for mobile applications is still under investigation. Additional equipment will be needed along with some modifications in the components designed for the primary application.

6) Maintenance: No more frequent than 1000 operating hours. Light maintenance actions on the primary application may take place no more frequently than 1000 consecutive hours of operation.

7) Lifetime: 40,000 hours. These 40,000 hours correspond to approximately 5 years of operation. A stack replacement and a check-up of all major components (heat exchangers, pumps and compressors, etc.) can take place at this point to continue operation and increase the lifetime.

\subsection{Preliminary Analysis}

As indicated from the CSD Process map and as described above, the design process is iterative. The $1^{\text {st }}$ Conceptual System Design is termed CSDv0 and is what was presented in the proposal. The design was further analyzed and problem statements were created for each of the major components including the following:
1) Air delivery
2) Air preheater
3) Fuel cell stack
4) Fuel delivery
5) Fuel processor
6) Power electronics
7) Steam generator
8) System controls
9) Water delivery

Functional descriptions of the major components are briefly described below: 
1) Air delivery: The air delivery components will deliver pressurized air for the fuel processor and the fuel cell stack. Components associated with air delivery include the air filter, compressor (or blower), air ducting, and flow valves to direct the required air flows to the fuel preheater/vaporizer and the air preheater.

2) Air preheater: The air preheater will use the SOFC combusted gas exhaust to preheat air to the SOFC stack

3) Fuel cell stack: The fuel cell will use air supplied by a compressor as the cathode gas, and anode gas supplied by the fuel processor to generate dc power. Both gases are to be heated to a temperature close to the fuel cell operating temperature.

4) Fuel delivery: The fuel delivery components will deliver pressurized fuel to the fuel processor via the fuel preheater/vaporizer. Components associated with fuel delivery include fuel filters, natural gas compressor, compressor motor, mobile fuel pump(s), pump motors and valves.

5) Power electronics: The power electronics will be used to convert stack dc power to ac and to provide required power to components within the system.

6) Fuel processor: The fuel processor will use preheated fuel, steam, and air as necessary to create an anode feed stream suitable for the fuel cell stack.

7) Steam generator: The steam generator will use the stack combusted gas exhaust to generate steam for the fuel processor. Steam generated is to have sufficient superheat such that the steam has no entrained moisture at the fuel processor inlet under any operational conditions

8) System controls: Functions of system controls include (i) coordination of subsystems for shared resources and efficient operation, (ii) efficient system regulation over the defined operating range, (iii) ensuring safe system operation through built-in tests, (iv) performing process and component health monitoring for improved life cycle, and (v) providing user interface and automated system operation for defined modes of operation.

9) Water delivery: The water delivery components will use tap water to deliver purified water to the stream generator for the fuel processor. Components associated with water delivery include water filters, water storage, water (booster) pump, pump motor, and valves.

The power and efficiency outputs from the preliminary analysis modeling are given in Table 2 .

TABLE 2. Preliminary Analysis: Overall System Performance

\begin{tabular}{|l|c|c|c||}
\hline \hline APPLICATION & STATIONARY & MOBILE & MILITARY \\
\hline NET SYSTEM POWER, $\mathrm{kW}$ & 5.0 & 5.0 & 5.0 \\
\hline NET SYSTEM EFFICIENCY, \% & 40 & 33 & 30 \\
\hline
\end{tabular}




\subsection{Stack Model Development}

A SOFC system model is needed and used in miscellaneous system analysis assignments to perform simulations on system designs under evaluation (candidate systems, improved configurations, etc.): material balance, heat balance assessment, current density, etc..

As a computation block, it is hooked up to Aspen Plus ${ }^{\circledR}$ (Aspen Technology, Houston, TX) to accommodate general system considerations.

A previously-developed stack model has been used in the initial SECA system development work. Plans are in place to develop and use 3 future iterations of this model (the "near-term model", "mid-term model", and "long-term model").

\section{Near-term model}

An initial version of the near-term model has been created based on limited single-cell performance data. The model predicts the single-cell voltage as a function of the current density, the reactant pressure, the cell temperature, the fuel and air stream compositions, the fuel and oxygen utilization, and the cell geometry and porosity. A semi-empirical approach has been used, in which cell mass transfer and kinetics phenomena were described analytically; however, a few critical parameters were obtained through a regression of experimental data. The model showed a fairly good agreement with experimental data. However, the data used in the regression had limited ranges for the majority of the parameters. Therefore, the model's usefulness for system trade studies is limited at this point, and more test data for model improvement and validation activities is required.

Figures $4 \mathrm{~A}, 4 \mathrm{~B}$, and $4 \mathrm{C}$ show some of the model's single-cell voltage predictions for the effects of pressure, temperature, and fuel utilization, respectively.

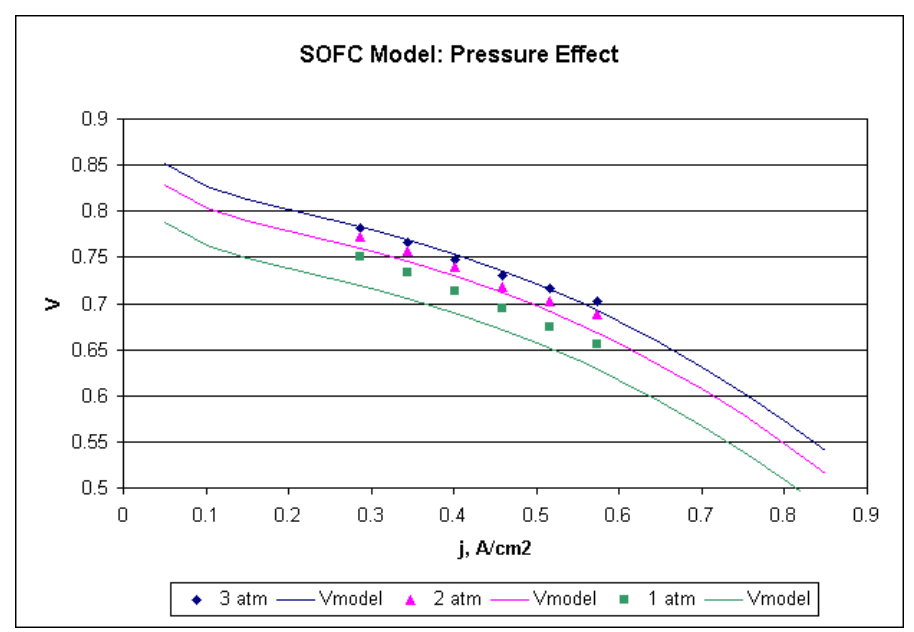

Figure 4A. Example of Near-term SOFC Model: Effect of Pressure 


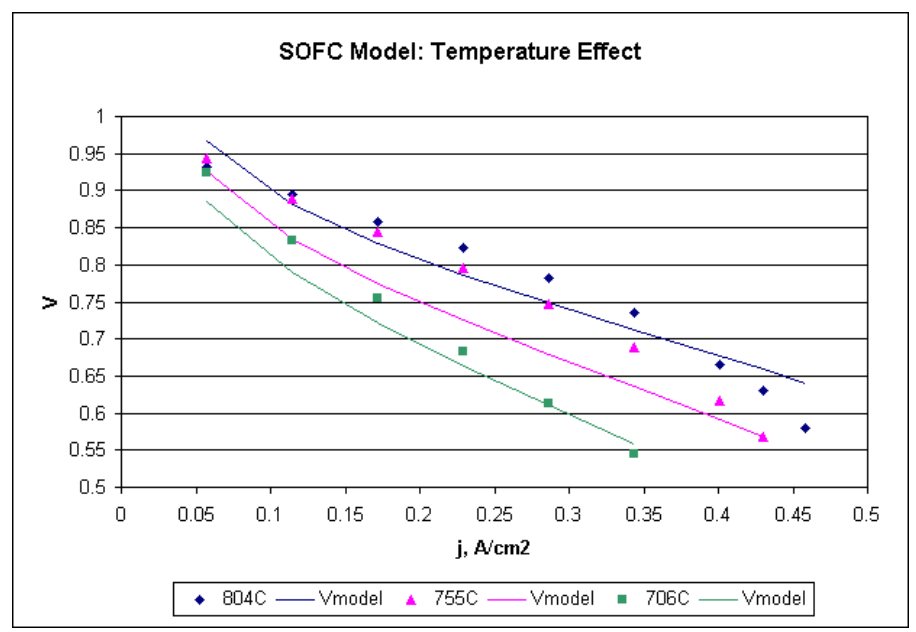

Figure 4B. Example of Near-term SOFC Model: Effect of Temperature

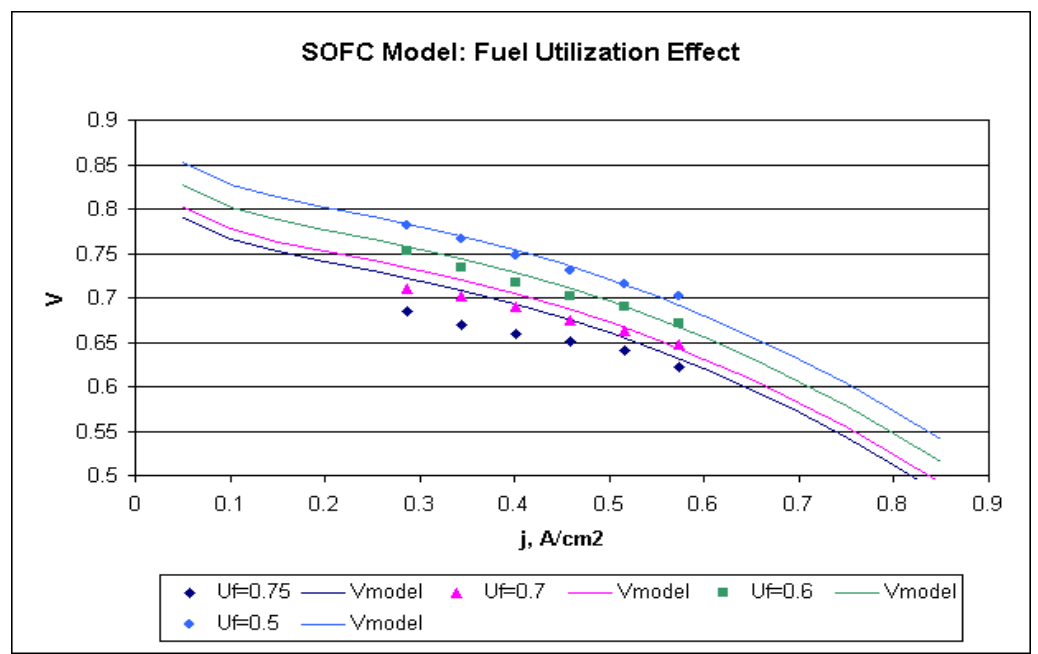

Figure 4C. Example of Near-term SOFC Model: Effect of Fuel Utilization

\subsection{System Model Development}

In order to evaluate the conceptual system design concepts, a steadystate performance model was developed using Aspen Plus ${ }^{\circledR}$. The model includes "blocks" that represent the major components including a FORTRAN block for the stack as described above. The model also includes a "SUMMARY" block in FORTRAN that allows output to an Excel spreadsheet; this SUMMARY block includes major component assumptions and outputs.

Samples of model outputs are given in the next section.

\subsection{System Concept Definition}

As described above, the concept definition process is an iterative process. At this time, CSDv0 has been specified. 
For the conceptual system design, the primary application is identified here to be a stationary application using natural gas. Component performances are to be estimated to determine the overall system output if gasoline (isooctane) and diesel (hexadecane) are used using the system performance model to create component requirement problem statements. It is expected that the plant rating (net power output) and efficiency with these other fuels may decrease when switching from natural gas to the mobile fuels.

Hence, the SECA Phase I Conceptual System Design will be based on producing 5-kW of net power for the natural gas fueled stationary application with all components designed for that application.

Component Requirements: Based on the design point steady-state simulations for CSDv0, problem statements were created for the major components including

- Air delivery

- Air preheater

- Fuel cell stack

- Fuel delivery

- Fuel processor

- Steam generator

- Water delivery

The data requirements that have been requested as a feedback to system concept designs from component designers include:

- Performance estimates for all applications

- Operational constraints

- Physical characteristics

- Start-up/shut-down considerations

- Operating life and maintenance

- Cost data

The initial feedback on component design provided in response to the " $\mathrm{v} 0$ " problem statement is used to create a preliminary component data basis. Its main items collected so far are indicated below:

Fuel Cell Stack Data Feedback: A set of "goal" polarization curves was created to represent the targeted level of performance required to achieve the program objectives indicated above. Present non-reformed gas cell performance and best engineering judgment were used to generate such curves for Phases I,II, and III. These curves are shown in Figure 5. 


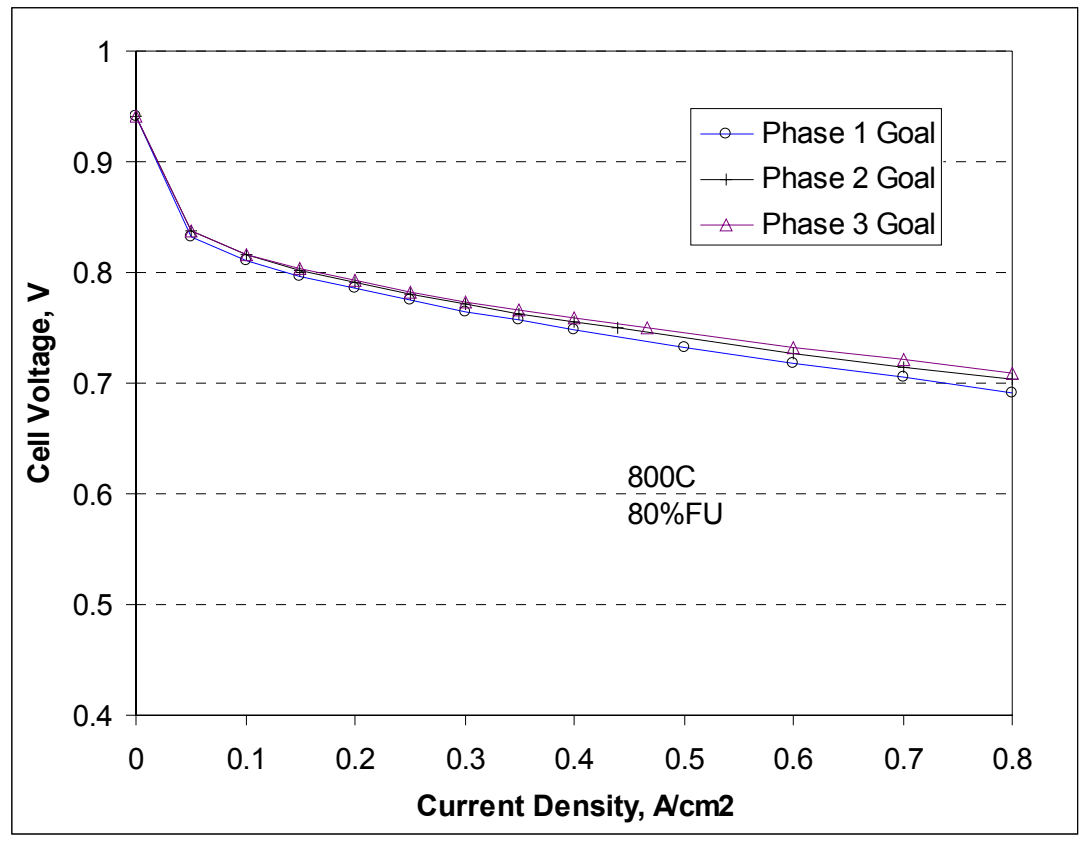

Figure 5. SECA Cell Performance Goal Curve

Fuel Processor Data Feedback: The ATR technology has been identified as the appropriate choice for this program. For the primary application, an ATR pre-reformer can potentially provide an anode feed gas (reformate) stream more favorable than the minimum requirements. Literature data suggests that for a methane feed, it is feasible to get up to 33 mole- $\%$ Hydrogen and about 45 mole$\%$ syngas $\left(\mathrm{CO}+\mathrm{H}_{2}\right)$ with minimal methane slip and no carbon.

Other data from other components are being developed.

Sensitivity Analysis: Important parameters to the system that will be evaluated include stack, fuel processing, thermal management, power electronics and other components. As the system requirements include aggressive system cost goals at $\$ 400 / \mathrm{kW}$, cost data must be incorporated into system sensitivity and trade studies. At this time, no cost data are available. However, it is expected to be available for trade analyses in the Concept Definition part of Task 1.1.

An efficiency analysis was performed based on the following parameters for the primary application:

Cell voltage (V): 0.65, 0.75 (baseline), 0.8 and 0.85

Fuel utilization (\%): 0.6, 0.8, 0.85 and 0.95

Cell delta-T $\left({ }^{\circ} \mathrm{C}\right): 50,100$ (baseline), 150 , and 200

where

Fuel utilization $=$ the moles of $\mathrm{O}_{2}$ reacted at the anode surface $/$ moles $\mathrm{O}_{2}$ to totally oxidize all fuel compounds in the anode feed 
Cell-delta- $\mathrm{T}=$ cathode gas inlet $\mathrm{T}$ - cathode gas outlet $\mathrm{T}$.

For these analyses, the baseline system efficiency was calculated at $37 \%$. Results of the sensitivity analyses are given in Figures 6, 7, and 8. It should be noted that these analyses are undertaken to see the $1^{\text {st }}$ order effects as one parameter is changed while maintaining the other parameters constant.

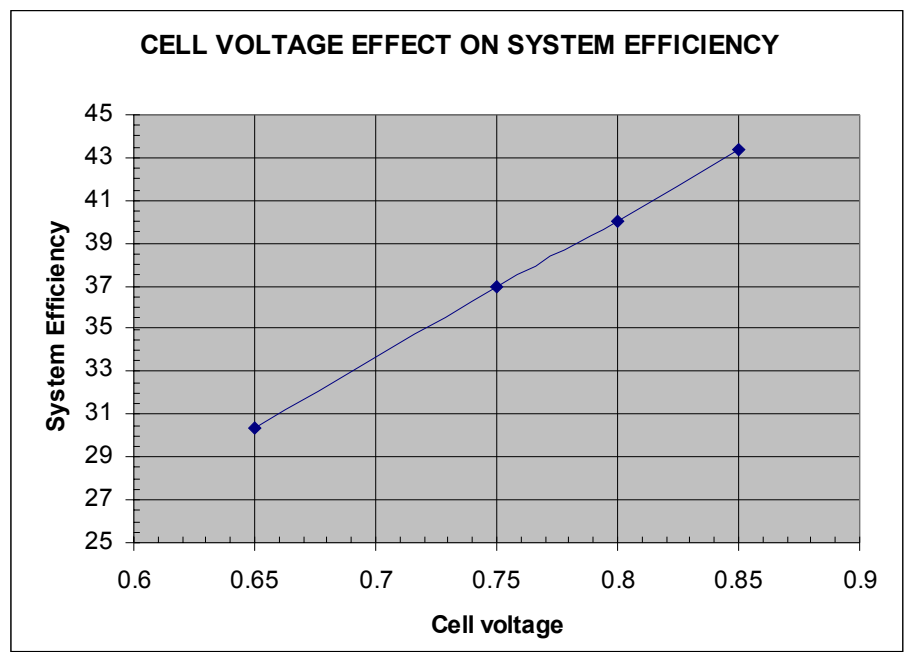

Figure 6. Cell Voltage Effect on Primary Application System Efficiency (CSDv0)

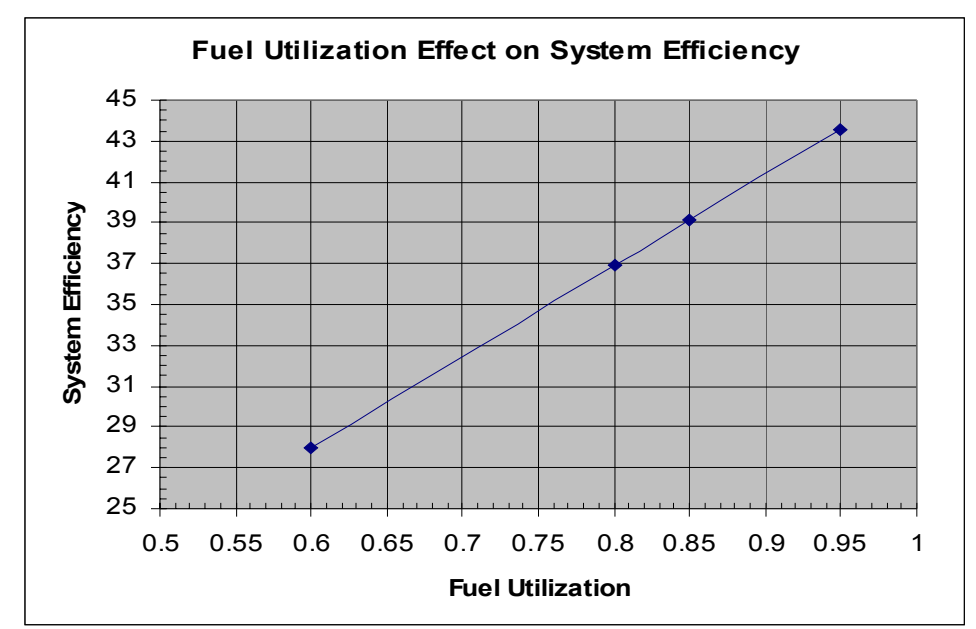

Figure 7. Fuel Utilization Effect on Primary Application System Efficiency (CSDv0) 


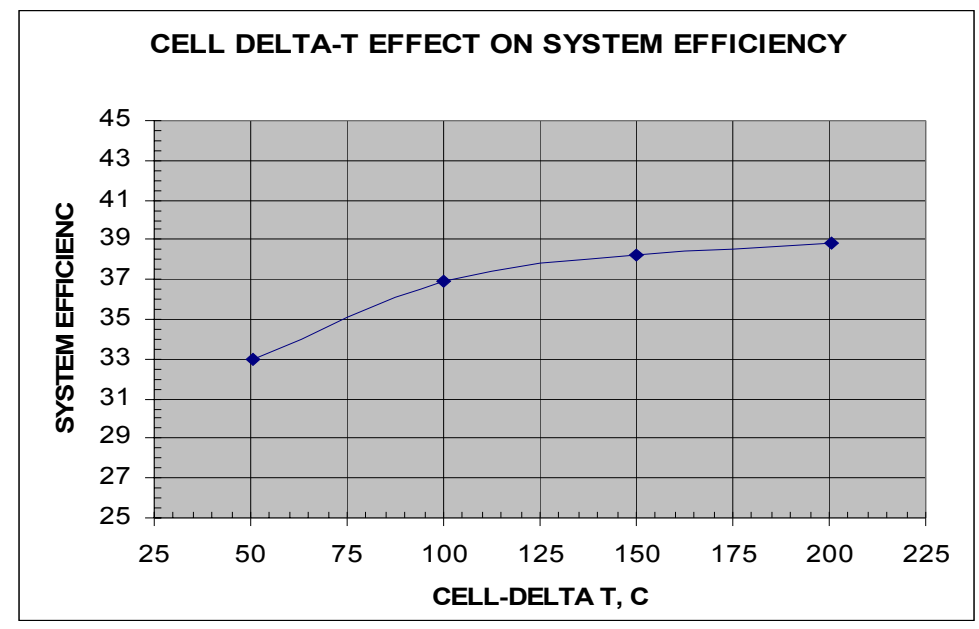

Figure 8. Cell Delta-T Effect on Primary Application System Efficiency (CSDv0)

\section{COST ESTIMATE}

\subsection{Preliminary Cost Estimate}

The proposed SOFC system has the potential of meeting the cost requirements for the program. Costs were estimated for a 5-kW SOFC system with annual manufacturing capacity of $250 \mathrm{MW}$.

The SOFC system is designed to be modular and suitable for various applications from stationary to transportation uses. The costs are calculated for a stationary system providing an ac output and operating on natural gas fuel. For applications requiring operation on liquid fuel, e.g. JP-8, and dc power output, the system is still modular but with a liquid fuel pump and without a dc/ac inverter. The estimated total costs for such a system are significantly lower.

The balance of plant (BOP) is expected to contribute the most to the total system cost. The fuel processor used for cost estimation purposes is a CPOX unit. Its cost is relatively low because the fast reactions in catalytic partial oxidation process make the unit compact and simple and fuel preheating is included in balance of plant (BOP).

\section{METHOD}

An integrated set of fuel cell business and technical models has been developed to address customer economics and market evaluation, system manufacturing costs, development costs and financing and financial performance. The system cost module provides a bottoms-up estimate of the overall system cost (i.e., cost of goods sold, including labor and materials) and is intended to be based on production volumes and include adoption of various levels of automation at appropriate production levels. The cost estimates 
presented were based on this system manufacturing cost module. The key components included in the cost module are:

- Materials: For each component of cell, stack, and system

- Capital Equipment: Type and size for each process step

- Labor: Number of persons required by process step

- Facilities: Land and utilities for manufacturing, assembly, and office spaces.

The general process for cost estimation of the proposed system involves the steps shown in Figure 9.

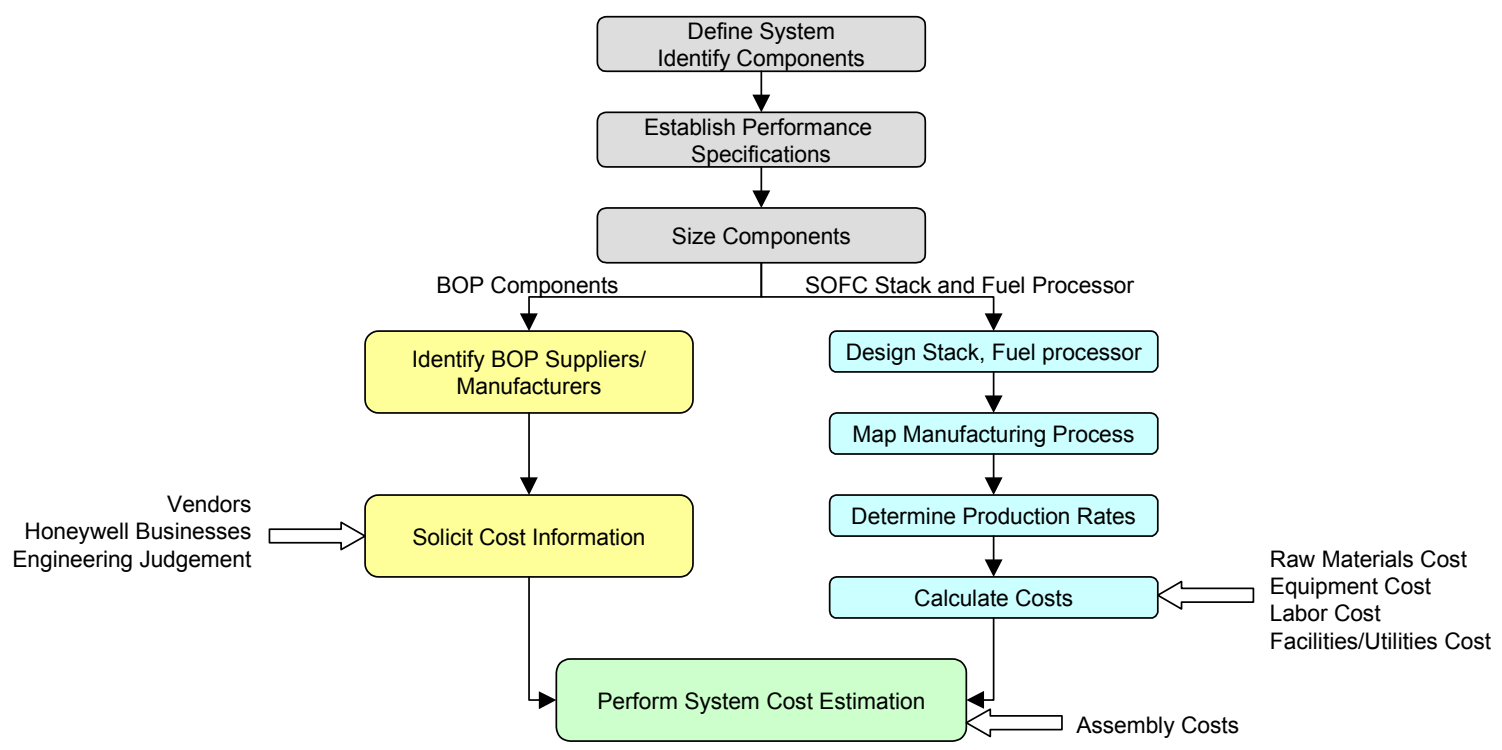

Figure 9. Schematic of Method for Cost Estimation

In this process, the estimate is divided into three major areas:

- SOFC stack manufactured in plant

- Fuel processor manufactured in plant

- BOP (consisting of power conditioning, heat exchangers and thermal management devices, gas delivery and exhausts, various controls, and packaging) procured from vendors including other Honeywell business units.

The stack and fuel processor are separated from other components because these units are specific to the proposed system and not available off the shelf.

\section{ASSUMPTIONS}

The proposal approach to cost estimation was using conservative system designs and market assumptions. The main system design assumptions used in the proposed cost estimates were: 
- A 5-kW stationary system operates on natural gas. The system includes a blower/compressor to compress natural gas and an inverter for converting dc power to ac.

- The SOFC stack uses Honeywell's baseline design with tape-calendered anode-supported thin-electrolyte cells and one-piece stamped metal interconnect.

- The fuel processor is a heterogeneous CPOX pre-reformer with supported catalysts. An SOFC stack with internal reforming capability would eliminate the cost of the fuel processor.

- All other BOP components are available from suppliers and vendors.

- For transportation and military applications, the fuel is assumed to be liquid, such as gasoline, JP, and diesel. In these cases, the system includes a liquid fuel pump but does not include an inverter.

are:

A few of the key manufacturing assumptions related to production costs

- Production rate is 50,000 units per year (250 MW/yr). The production rate was selected to validate DOE's estimates to meet objectives, but as the program progresses and the design matures, the minimum production rate to meet the cost goals will be examined. In general, a lower production rate will make the business case more attractive for penetrating markets. In addition, if the Phase III cost goal of $\$ 400 / \mathrm{kW}$ can be achieved with less than 50,000 units per year, higher production rates will lead to even lower costs.

- A single plant located in the Southwest will house all the manufacturing activities for the system and components.

\section{COST ESTIMATE DETAILS}

\section{Stack}

The Phase III cost estimate breakdown for a stack including manifolds, loading mechanism and insulation is shown in Figure 10. The estimated cost decreases substantially from Phase I to Phase III. The cost reduction from Phase I to Phase II to Phase III is achieved through a combination of:

- Increased yield through Six Sigma process improvements

- Reduction in key materials cost as a result of market competition among suppliers

- Use of materials with lower purity

- Component designs that are simpler and more amenable to high-volume manufacturing and

- Labor reduction through process automation.

The breakdown of stack costs for Phase III can be visualized in Figure 10. It is apparent that the major contributor in the stack costs is the materials cost, which accounts for about half of the total cost. 


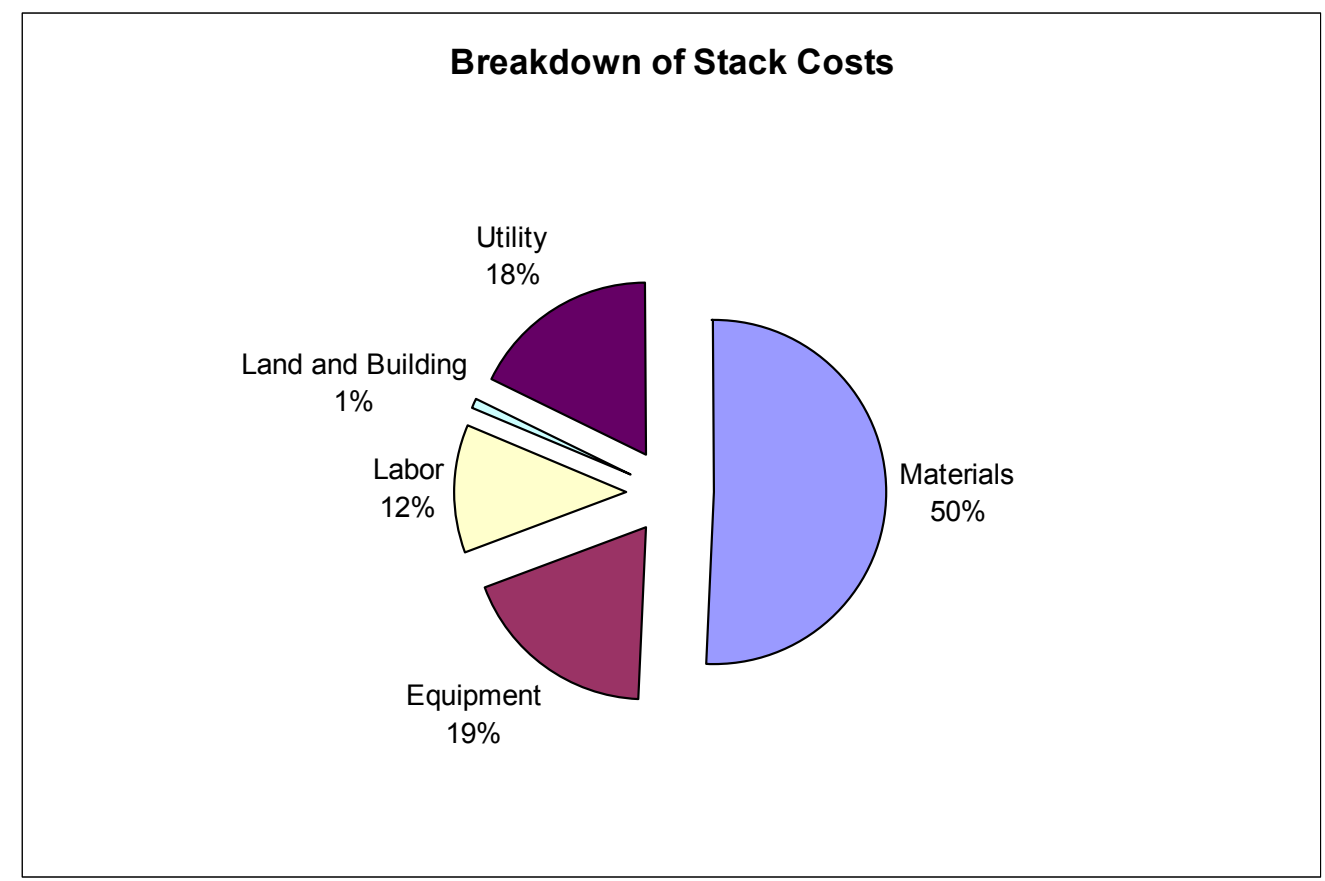

Figure 10: Breakdown of Stack Cost for Phase III

Materials Cost-For the above-described baseline components and processes, the cost projection was based on the anticipation of competitive prices from multiple suppliers and relaxation in material specifications.

Equipment and Labor Costs-Major equipment items were listed along with their associated costs. Significant investment in robotics and automation was assumed to minimize labor and improve process yield. the Southwest..

Plant and Utility-The manufacturing plant was assumed to be located in

Utility was estimated assuming a $6000 \mathrm{hr}$ of full-capacity operation and $2760 \mathrm{hr}$ at one-tenth capacity.

\section{Fuel Processor}

The fuel processor cost was estimated assuming a heterogeneous CPOX pre-reforming process. For cost estimating the fuel processor, the same method as the stack has been used.

The total cost for the pre-reformer was estimated in terms of materials, labor, amortized equipment for manufacture, and utilities. The manufacturing methods for Phase I were assumed to be manual. The cost of CPOX fuel processor for Phase II was estimated using semi-automated manufacturing and improved catalyst utilization over Phase I. 


\section{Other BOP}

The costs of the other BOP components were estimated with a combination of vendor quotes, cost information within Honeywell, and engineering judgement.

\section{Component Cost Risks}

Inverter: Of the various components, the inverter requires the most effort in cost reduction; current costs exceed $\$ 800 / \mathrm{kW}$. Significant work is being done in the area of inverter cost reduction for automotive applications with the goal of reducing inverter cost by 95 percent. The current major cost of inverters comes from design development, raw material, and product assembly. The latter two tie in with the design. Inverter developers are focusing on the development of modular design and innovative pressure contacts to drive down both device assembly and raw material cost.

Power Conditioning for Transients: While the system is designed to respond to load change requirements, a battery storage may be required as part of the power-conditioning subsystem.

\subsection{Go-Forward Plan}

\section{Cost Model}

The cost estimate model that was created in the preliminary analysis described above was dedicated to a particular stack and system design, with fixed assumptions that did not allow the flexibility to accommodate other options. As the program advances, a definite need for cost sensitivity analyses will arise. An effort has therefore been undertaken to create a flexible, user friendly model that will be used to generate extensive trade studies. The areas for which the existing model requires such improvements are discussed below.

A given cell and stack design is a common assumption being used as a basis for generating stack cost estimates in the current model. As of now, there is no provision to accommodate other designs in the model, and therefore, no capability to investigate the effect of stack design on the costs, which should, in fact, be quite significant. The plan is then to update the model such that the stack design becomes an input of the cost estimate calculations. This effort is ongoing.

Similarly, a given operating point (in terms of current density, cell voltage) is being used with no opportunity to vary it as an input parameter. The plan is to make the model more flexible by giving the user the freedom to choose the operating point they want, to investigate its impact on costs. This will be done by implementing a polarization curve that will be used to relate current density to cell voltage and power density. The user will pick one of the three above variables to analyze its impact and the model will generate the associated operating point and calculate the stack overall geometry, and thus its costs. Ideally, this polarization curve would account for the effects of stack temperature and pressure, so that these variables could be used as input parameters as well. 
A standard manufacturing approach was used as the basis to estimate the costs related to manufacturing equipment and labor. Here too, one wants to have the opportunity to explore the effect of manufacturing processes on the overall cost. The model will, therefore, be improved so that it can handle different manufacturing options and allow the user to switch from one process to another to investigate the impact on costs.

In addition to these improvements in flexibility, a careful assessment of the general assumptions that impact the costs is required to refine the cost model. The materials-to-product yields were so far assumed on the basis of experience and engineering judgment. An activity has started to better assess the value of these key-parameters. Additionally, a more thorough estimation of facility and man-labor cost-related assumptions also needs to be undertaken to enhance the fidelity of the model.

The last major improvement that needs to be implemented in the model concerns its ability to handle volume-dependent costs. The model currently uses a single set of component cost data, representing either "unit costs" or "bulk costs". An activity currently in progress consists of creating a capability to insert a cost schedule, that will allow the user to pick a given production volume, and investigate its effects on overall costs.

\section{Cost Estimates}

The actual cost data for the different components and subsystems of the system were compiled from preliminary discussions with vendors or on the basis of engineering judgments. A more thorough investigation needs to take place, where high-volume costs need to be assessed with more refinement.

For each sub-system, the costs will be assessed on two different bases: a prototype system, associated with today's available components costs, and a conceptual design, with fewer components, associated with high fidelity largevolume cost estimates.

Stack: As the stack design effort is still in progress, no significant revision in the stack costs has been generated yet. Candidate stack designs are currently being used to help generate the improvement in flexibility in the cost model mentioned above. The materials costs of the stack are in the process of being estimated by soliciting vendors for both the "prototype" (single unit) and the "conceptual" (high-volume) configurations.

In parallel to this work, different manufacturing approaches are currently being investigated. These different options will allow the identification of the equipment needed to complete the consecutive manufacturing steps. The costs associated with these pieces of equipment will then be generated based on quotations obtained from vendors.

Ultimately, a manufacturing cost, including equipment, labor and facility costs, will be generated and will be added to the materials cost to form the total stack costs. Such total stack costs will be generated for both configurations as mentioned above. 
Fuel Processor: The fuel processor cost estimation work that was undertaken as the preliminary analysis assumed the use of the CPOX technology. Further assessment work has been initiated in the scope of Phase I of this program and seems to indicate that the ATR technology may be better suited for the defined applications. No thorough cost estimation has started yet on this item.

Other BOP: In this early stage of the program, a parts list has been created to account for all the components needed in a prototype version of the system. This prototype system is currently used as the basis to generate the conceptual system. An assessment on how to reduce the parts count, how to minimize the constraints on key components to simplify their design or how to optimize the controls scheme (optimal use and location of sensors and valves) is an on-going process.

At this point, the costs for the components of the balance of plant of the prototype design have been assembled either by soliciting quotations from vendors or by using best engineering judgment.

\section{STACK TECHNOLOGY DEVELOPMENT}

\subsection{Stack Design Evaluation}

The stack design development task is to develop a planar design incorporating alternating layers of high-performance, thin-electrolyte cells and thin metallic interconnects for reduced-temperature operation of 700 to $800^{\circ} \mathrm{C}$. The stack operates at ambient pressure with preheated air and reformed fuel.

The stack design development effort has followed the Design-for-Six-Sigma process to:

- Define the stack specifications referred to as CTQ's or Critical to Quality

- Flowdown the CTQ's to the component level and generate the component specifications

- Evaluate the baseline through the benchmarking and establish gaps

- Identify the risks associated with the design

- Start concept design

\section{Stack Design Methodology}

Design for Six Sigma (DFSS) has been selected for stack design and development. DFSS is a disciplined approach for designing products and processes based on Six Sigma principles. It focuses on the customer needs or CTQ's (Critical to Quality), on reducing variability, and on prediction of the product quality during design. Following the DFSS process will help to reduce design cycle time and achieve the customer's CTQ's, including cost, reliability, and performance. 


\section{Stack Specification}

Based on the SECA system preliminary design, the requirements, i.e., CTQ's, have been flowed down to the stack-level. In order to meet the net system power output of $5 \mathrm{~kW}$, the stack needs to be sized at $5.65 \mathrm{~kW}$ to provide the power for BOP and cover the losses in power electronics.

\section{Bill of Materials}

Based on the preliminary stack design, a Bill of Materials (BOM) has been generated. The BOM includes the repeat and non-repeat parts. The BOM includes all the parts for the single stack, connection of the multi-stacks, the stack housing and insulation, and stack interfaces with systems, like flanges, and etc..

\section{Component Specifications}

The component specifications set the requirements for each component in a stack design. The requirements for these components are flowed down properly from the stack level CTQ's to ensure the final design will meet the customer's requirements.

The CTQ's of the stack are being flowed down to the stack components for the component specifications. The focus of the CTQ flowdown is on performance, which will set the requirements for the electrolyte, cathode, anode, interconnect, and bonding materials. A performance transfer function linking the stack performance and the components has been generated and is used for the performance flowdown. This task will be completed in next reporting period.

\section{Benchmarking}

The benchmarking assesses the current internal stack designs. The assessment includes the performance, reliability, cost, manufacturing, and etc. The benchmarking will provide the information of the best internal design and set a baseline for the new concept design.

\section{Performance}

The current designs have been evaluated. A model predicting the stack performance at the reformed gas conditions has been generated.

Stack tests under reformed gas conditions are being planned and will be conducted to provide stack baseline performance data under the reformed gas conditions and to validate the prediction model.

\section{$\underline{\text { Cost }}$}

The cost model of stack has been reviewed and revised based on the new preliminary bill of materials, or BOM. The cost breakdown of the stack is estimated as followed with the material accounting for half of the stack cost:

Material $\quad 50 \%$ 
Equipment $\quad 18.8 \%$

Labor $\quad 12.9 \%$

Utility $\quad 17.6 \%$

Land $\quad 0.8 \%$

Reliability

The current thermal cycling and long-term performance data is being compiled and evaluated to form the baseline for the reliability. The current thermal cycling degradation is $2.3 \%$ per 10 cycles and the long-term degradation is about $3.5 \%$ per 500 hours. The longest stack test to date has been 3200 hours. Another stack has been tested through 12 cycles.

\section{Gaps}

The baselines for the current stack designs in the areas of performance, degradation, endurance, and cost have been compared with the customer requirements to identify the key gaps. The biggest of these gaps, not surprisingly, is the cost, with the performance ranked second.

Stack cost is closely tied to stack performance. A lower-performance stack requires a larger stack, which means higher cost. If the stack performance can be improved to meet the target, the stack cost gap will be reduced dramatically. Therefore, performance is the key gap on which to focus.

\section{Risk Assessment}

The failure modes of the stack are being documented and compiled. All these stack failure modes are being analyzed and ranked according to Failure Mode and Effect Analysis (FMEA) process. The high-risk process or feature is being identified and abatement plans are being generated to address the highrisk areas.

\section{Conceptual Designs}

The initial stack design effort is focused on interconnects for achieving uniform flow field and reducing pressure drops in the cell air and fuel manifolds. A more uniform flow field will increase fuel utilization, improve the stack performance, and help close the two largest gaps, cost and performance.

Several potential design concepts have been generated to achieve uniform flow fields and reduce pressure drops though the cell manifolds.

\subsection{Materials Evaluation and Optimization}

Under this task, progress has been made in the following areas:

- Gap analysis between target and current performance

- Oxidation estimation of baseline interconnect material 
Gap analysis: A fuel cell performance model is being established based on fuel cell electrochemistry and experimental data. The model has been used to identify the gap between the program goal and current cell performance. Due to limited availability of cell data, especially those data under high utilization, establishment of this model becomes critical in quantifying the performance gap. Figure 11 shows the performance goal curves in 3 phases and the simulated current performance range (betweeen the lines labelled $L$ and $H$ ).

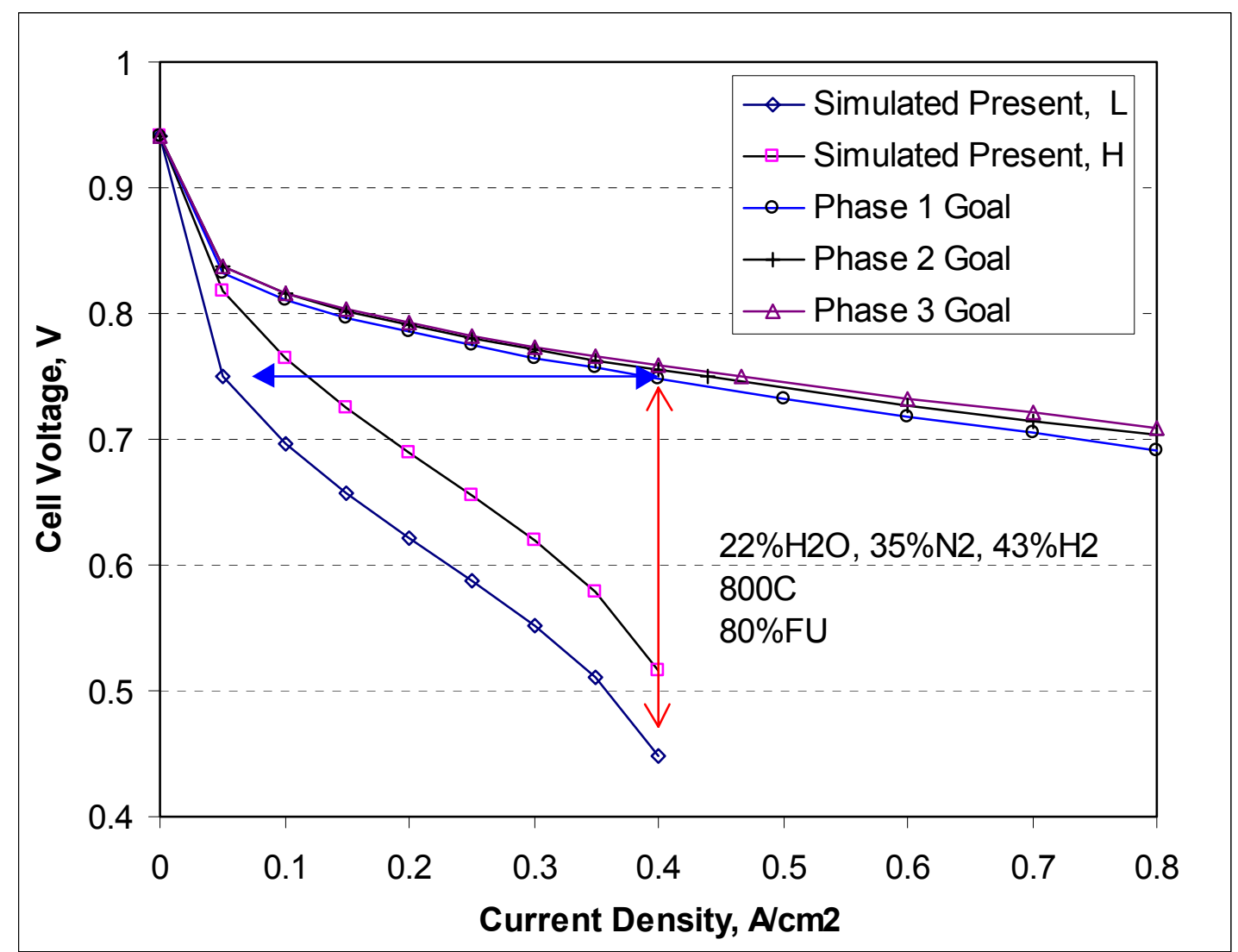

Figure 11 Performance Gap between Target and Simulated Present Performance.

In performance gap analysis, it was found that the allowable cell loss in area specific resistance (ASR) varies with feed fuel quality. Generally, the better the fuel (high hydrogen and low water content), the higher the allowable ASR, and therefore a smaller technology gap. Based on this analysis, approaches are being outlined to improve cathode, anode, and interconnects to achieve the program goal.

Interconnect: Metal interconnect oxidation is inevitable during SOFC operation. The oxide growth rate of baseline materials was estimated at different temperatures based on available kinetics data. Even though the oxidation is relatively slow and chromium oxides have some conductivity, the oxide-scale thickness and resistance can be significant at 40,000 hours. Actions are being 
taken to identify and evaluate alternative materials as well as to develop coatings to minimize the metal oxidation.

\subsection{Thermal cycling}

The fuel cell stack and ancillary components comprise a range of materials with wide-ranging coefficients of thermal expansion. Consequently, measures must be taken in the design and choice of materials to minimize damage done during expansion and contraction of the various components during thermal cycles. The baseline design is very robust owing in part to the metallic interconnect structures which provide strength and compliance.

Ideally, an understanding of the thermal cycling damage mechanisms can serve to inform the stack design process. In addition, thermal cycling experiments can be designed to guide materials selection during the design process.

\section{Approach}

The thermal cycling schedule follows a two-pronged approach to understanding and improving upon the robustness of the stack and its ancillary components. First, a series of sub-stack thermal cycling experiments will be performed. These experiments are scheduled around the stack design reviews and down selection processes to provide stack designers with up to date gap analysis and guidance.

\section{Progress}

First, to more fully understand which aspects of the existing stack design are susceptible to thermal cycling failure, a Failure Mode and Effect Analysis (FMEA) was conducted. The analysis revealed that regions containing ceramic to metal bonding and metal to metal bonding are the most vulnerable to thermal cycling failure. Experiments are being devised to isolate thermal cycling damage on these bonded components.

All existing thermal cycling empirical data were gathered and analyzed for trends. Tests on the latest stack configuration yield a cell voltage degradation rate of $2.3 \%$ per 10 cycles. This value represents a gap of $1.3 \%$ from the SECA Phase I goal. However, these data were compiled over hundreds of hours at load and the existing, iso-thermal degradation rate was also significant during this test. The tests will be repeated with more rapid thermal cycling events to establish the baseline degradation values.

In order to initiate thermo-mechanical modeling efforts, elastic property data are being gathered for each material in the existing stack design. In addition, a solid model of the current stack is being developed for initial modeling efforts. 


\subsection{Stack Lifetime}

The goal of this task is to quantify stack degradation rates (and therefore stack operating lifetime) as a function of operating conditions and to map the controlling degradation mechanisms in various operating regimes. To date, the work has focused on stacks and modules operating in pure hydrogen at low fuel utilization.

\section{Background and Prior Results}

From prior work, two major degradation mechanisms are anticipated to be active in SOFC stacks, both related to chromium oxide formation on interconnect metals. The first mechanism is oxide scale growth: at stack operating temperatures, a relatively low-conductivity chromia scale grows on the interconnect and increases the electrical resistance of the stack. The kinetics of this mechanism are well understood. The second mechanism is contamination of the cathode active areas by transport of chromium from the interconnect. The kinetics of this process are not well understood.

When a SOFC stack is tested at constant current density $j$ and constant fuel and oxidant flow rates, the stack voltage $V$ will be related to the area specific resistance $A S R$ of the stack. Under these conditions, degradation will be observed as a decrease in operating voltage (and therefore stack power) and a corresponding increase in ASR. The relevant equation is:

$$
V(t)=V_{0}-j\left(A S R_{0}+D t^{\frac{1}{n}}\right)
$$

where $V_{0}$ is the extrapolated 0 -current voltage (which is typically slightly different from the actual stack open-circuit voltage or OCV), $A S R_{0}$ is the constant component of stack resistance, $n$ is the order of the kinetics of the degradation mechanism (e.g. $n=2$ for parabolic kinetics). $D$, then, is the relevant timederivative of the resistance:

$$
D=\frac{d A S R}{d t^{\frac{1}{n}}}
$$

The $D$ parameter will be used to quantify the steady-state degradation rate and compare to models.

Oxide scale growth kinetics for the baseline metal interconnect are well understood, as is the conductivity of the scale. Therefore, the expected value of the D parameter for a layer of oxide can be calculated. In a SOFC stack, there are potentially two layers of oxide per cell. However, one of these layers is on the fuel side of the cell, in a reducing atmosphere, and this layer has typically been observed in our experiments to be thinner. Therefore, for degradation dominated by oxide scale growth at $800^{\circ} \mathrm{C}$, we expect to observe a value of $\mathrm{D}$ between $1 x$ and $2 x$ the value for a single oxide layer. In stack and module tests, 
we observe $D=1.6 \mathrm{x}$ the expected single-layer value, which is consistent with this model.

Under a range of stack operating conditions, the degradation data is consistent with a controlling mechanism of interconnect oxidation. Under other conditions, a change in controlling mechanism has been observed.

\section{Continuing Work}

In the current baseline stacks, there are multiple degradation mechanisms which can be active and will reduce life. These mechanisms include interconnect oxidation and chromium contamination of the cathode.

Work is continuing to develop a mechanism map, determining what mechanism controls under what operating conditions. The kinetics of the different mechanisms are also being evaluated. Analytical work is also planned to examine the cathode and further study the degradation mechanisms.

\section{5 $\underline{\text { Performance Evaluation and Improvement }}$}

The purpose of this task is to test and evaluate fabricated cells and stacks to verify electrochemical performance under specified operating conditions of temperature, fuel and air utilization. Cell polarization and open-circuit potential will be measured, and area-specific resistance will be determined. The performance losses of various components will be identified by using techniques such as ac impedance and dc polarization. Based on these measurement electrode microstructures and electrode/electrolyte interfacial characteristics will be engineered and optimized to reduce electrode polarization losses.

During this reporting period, a 1" single cell assembly and testing procedure was developed. The purpose of this procedure is to provide a standard for cell/stack performance evaluation and material screening. A 4 3/8" radial single cell was assembled for baseline performance measurement. Syngas which contains hydrogen, water, carbon dioxide, and methane to simulate the reformate from ATR will be used in this measurement. The test stand including syngas supply system for the $43 / 8$ " radial single cell test is constructed using existing equipment. The cell will be tested based on the test plan developed in this task to provide performance baseline for stack and system design.

\subsection{Stack Fabrication and Processing}

The cell fabrication process is based on the tape calendering process for producing high performance thin-electrolyte cells. A schematic of the fabrication process is shown in Figure 12. This process is ideally suited for high volume, low cost production of SOFCs. The cells fabricated by this process consist of thin electrolytes ( $\sim 5-10$ micrometers) supported on a thicker electrode (e.g. 250-300 micrometer anode). In the calendering process, electrolyte (yttria-stabilized $\mathrm{ZrO}_{2}$, or YSZ) and anode (NiO/YSZ) powders are first mixed with organic binders and 
plasticizers in a high-shear mixer. The plastic masses with a doughy consistency are rolled into tapes using a two-roll mill. Electrolyte and anode tapes of certain thicknesses are laminated and rolled into a thin bilayer tape. This thin tape is then laminated with a thick anode, and the laminate is rolled again into a thin bilayer tape. This process is repeated until a desired thickness of electrolyte and anode is reached. The final bilayer is fired at elevated temperatures to remove the organics and sinter the ceramic. A cathode layer (Sr-doped $\mathrm{LaMnO}_{3}$, or LSM) is then applied by screen printing on the electrolyte surface of the sintered bilayer to form a thin-electrolyte cell.

Tape Forming

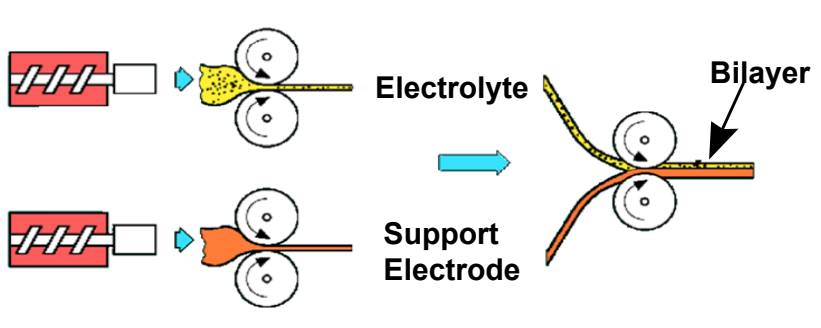

Deposited Electrode Application

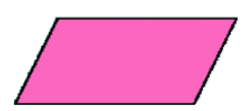

Rolling

Firing

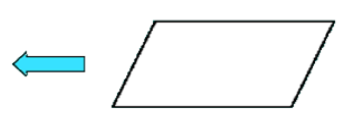

Rolling

Thin Electrolyte on Support Electrode Layer

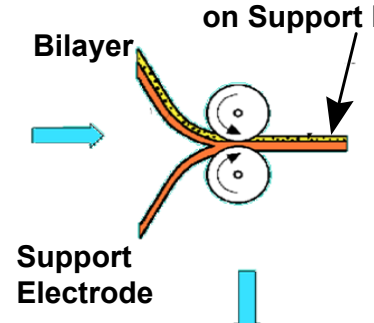

Cutting

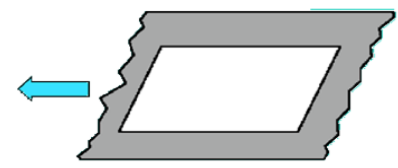

M-12569.ppt

Figure 12. Schematic of Tape Calendering Process

Initial work involved creating process flow diagrams for the cell fabrication process and verifying and updating process procedures. These documents will be used to create a baseline and to develop data for the system cost analysis. As the process is modified and optimized these documents will be updated to reflect and capture the changes. Similar documentation was done for the stack assembly process. This documentation was done in a more generic manner due to the fact that the stack design is not finalized and a large portion of the process is dependent on the stack design.

Another area of initial work has been in the area of scale-up of the component size. Prior to this program the typical cell footprint area has been on the order of $100 \mathrm{~cm}^{2}$. This size limit was not due to process limitations, but rather design requirements of past work. Preliminary trials have started in the areas of bilayer and metallic interconnect fabrication. The initial goal is to fabricate components with at footprint area of $325 \mathrm{~cm}^{2}$. This size is limited by current rolling and sintering equipment, which is expected to be increased within the timeframe of the current program. Cells of this size have been fabricated and firing trials are underway to determine the appropriate conditions for sintering that 
produce cells with the proper characteristics while maintaining an acceptable yield.

\section{FUEL PROCESSING}

\subsection{Assessment}

This effort focused on conducting a fuel processing technology assessment. Four fuel processor technologies were considered as part of the assessment, and included steam reforming, auto-thermal reforming (ATR), catalytic partial oxidation (CPOX), and electrochemical partial oxidation (EPOX). The technology assessment highlighted the strengths and weaknesses of the hydrocarbon fuel reforming technologies and considered the potential of each of the technologies for the 3-10 kW SOFC application targeted in the SECA program. The assessment process activities included the following:

- A description of each fuel processor technology and its advantages and disadvantages

- A literature survey to capture the current state of technology in the various reforming areas

- Thermodynamic analysis to develop the relative reformate compositions

- A high level "system fit" schematic for each reformer technology to capture the important system tie-ins and the specific requirements on the balance of plant - A quality functional deployment (QFD) analysis to potentially downselect the most feasible fuel processor technology for the SECA program application

- Re-activation of an existing fuel processor test laboratory

\section{Fuel Processor Technology Descriptions}

The four fuel processor technologies considered for the SECA program included steam reforming, ATR, CPOX, and EPOX. The sections below describe each of these technologies and their advantages and disadvantages.

\section{Steam Reforming}

Catalytic steam reforming of natural gas is one of most energy efficient ways to produce hydrogen and carbon monoxide. Steam reforming does not require the mixing of air in the reaction mixture, and therefore, has a higher hydrogen concentration in the end product. Elimination of oxygen from the initial fuel mixture also improves the overall system efficiency by removing energy loss due to the catalytic combustion. Steam reforming, however, does require an external heat source due to endothermicity of the reaction, and, therefore, can only realize its advantage when the effective heat utilization from SOFC stack can be achieved. The cost of conventional steam reforming catalysts is relatively low, although they tend to be vulnerable to the sulfur based catalyst poisoning components. Steam reforming technology is widely used in industrial syngas production in very large scales. A summary of the advantages and disadvantages of steam reforming are presented in Table 3. 
Table 3 Steam Reforming Advantages and Disadvantages

\begin{tabular}{|l|l|l|}
\hline Characteristic & Advantage & Disadvantage \\
\hline Hydrogen Yield & $\begin{array}{l}\text { Generally higher than } \\
50 \% \text { based on simulation } \\
\text { at T }>600^{\circ} \mathrm{C} \text { for S/R }=1, \\
\text { very promising to reach } \\
\text { final target stack } \\
\text { efficiency }\end{array}$ & $\begin{array}{l}\text { Potential high level of } \\
\text { carbonaceous material } \\
\text { formation }\end{array}$ \\
\hline Heat Requirement & $\begin{array}{l}\text { Heat generated from } \\
\text { SOFC can be used to } \\
\text { drive steam reforming } \\
\text { reaction with overall } \\
\text { higher system efficiency }\end{array}$ & $\begin{array}{l}\text { External heat transfer } \\
\text { device is required, } \\
\text { therefore results in } \\
\text { system complexity and } \\
\text { potential higher cost }\end{array}$ \\
\hline Startup/Transients & $\begin{array}{l}\text { Selative stable during } \\
\text { transition operation } \\
\text { igniter to start up } \\
\text { although the catalyst bed } \\
\text { can be used for catalyst } \\
\text { combustion tentatively. } \\
\text { Heat transfer efficiency } \\
\text { and higher volume } \\
\text { makes the start-up slow }\end{array}$ \\
\hline
\end{tabular}

ATR

ATR presents a middle of the road choice, providing reasonable yields in terms of hydrogen yields. The process is catalytic and involves input streams of both air/oxygen and water/steam that will react with the fuel stream to produce syngas. Effectively, an ATR combines the exothermicity of a partial oxidation reaction (hydrocarbon fuel reacting with air) to provide the heat required for the endothermic steam reforming reaction that occurs on the same catalyst or on a steam reforming catalyst located in close proximity to the partial oxidation catalysts. The reformate quality, defined in terms of hydrogen mole fraction in the reformate stream from an ATR is thus superior to the CPOX reformate but not as good as the steam reforming reformate. The advantage though is that an ATR is a thermally neutral system component, thus more responsive than a steam reformer and moderate in cost, size and weight requirements. On the downside, a more extensive control system is needed for ATRs to ensure robust operation of the fuel processing system. Advantages and disadvantages of ATR is summarized in Table 4.

Table 4. ATR Advantages and Disadvantages

\begin{tabular}{|l|l|l|}
\hline Characteristic & Advantage & Disadvantage \\
\hline Hydrogen Yield & About 50\% concentration & $\begin{array}{l}\text { Still not up to par for } \\
\text { providing very high } \\
\text { system level efficiencies, } \\
\text { especially if the fuel }\end{array}$ \\
\hline
\end{tabular}




\begin{tabular}{|l|l|l|}
\hline Heat Requirement & None & $\begin{array}{l}\text { utilization on the stack } \\
\text { side is not high. }\end{array}$ \\
& $\begin{array}{l}\text { May need startup heat, } \\
\text { and control systems to } \\
\text { switch between lean } \\
\text { burning and ATR regimes }\end{array}$ \\
\hline Startup/Transients & $\begin{array}{l}\text { Moderate. Can be set up } \\
\text { to fast response times by } \\
\text { switching between CPOX } \\
\text { and ATR (relying in } \\
\text { CPOX portion for the } \\
\text { faster response time) }\end{array}$ & $\begin{array}{l}\text { Transient fluctuations for } \\
\text { load matching may be as } \\
\text { much as 1-10 per } \\
\text { second... Such } \\
\text { deviations will reflect on } \\
\text { efficiency levels if we are } \\
\text { switching between } \\
\text { CPOX/ATR for } \\
\text { responding to transients }\end{array}$ \\
\hline
\end{tabular}

\section{CPOX}

In CPOX, the hydrocarbon fuel is reacted with air on a catalyst and the catalytic combustion is essentially prevented from going to completion. By controlling the amount of oxygen available for the complete combustion of the hydrocarbon fuel, the reformate will yield partial oxidation products, $\mathrm{CO}$ and Hydrogen. Due to its fast reaction rate, the CPOX reformer has high response times. The process conditions that promote the constrained oxygenation of the fuel provide for a compact reactor system. Also, the CPOX system is comparatively more fuel flexible than steam reforming or ATR and can tolerate higher levels of trace sulfur contaminants in the hydrocarbon fuels. The disadvantage of this technology is the low yield of hydrogen in the syngas reformate stream. Table 5 presents the advantages and disadvantages of CPOX.

Table 5. CPOX Advantages and Disadvantages

\begin{tabular}{|l|l|l|}
\hline Characteristic & Advantage & Disadvantage \\
\hline Hydrogen Yield & $\begin{array}{l}\text { Relatively low yield can } \\
\text { be tuned by improving } \\
\text { catalyst and convert } \\
\text { some CO back to } \mathrm{H}_{2}\end{array}$ \\
\hline Heat Requirement & $\begin{array}{l}\text { No external heat } \\
\text { required. The system is } \\
\text { exothermic }\end{array}$ & $\begin{array}{l}\text { The heat generated from } \\
\text { the reaction needs to } \\
\text { removed or utilized in the } \\
\text { system }\end{array}$ \\
\hline Startup/Transients & $\begin{array}{l}\text { Startup is fast. Transient } \\
\text { test is relatively easy to }\end{array}$ & $\begin{array}{l}\text { High temperature } \\
\text { startup/shutdowns may }\end{array}$ \\
\hline
\end{tabular}




\begin{tabular}{|l|l|l|}
\hline control & $\begin{array}{l}\text { cause catalyst } \\
\text { degradation }\end{array}$ \\
\hline Additional & $\begin{array}{l}\text { Startup is fast. Transient } \\
\text { test is relatively easy to } \\
\text { control }\end{array}$ & $\begin{array}{l}\text { High temperature } \\
\text { startup/shutdowns may } \\
\text { cause catalyst } \\
\text { degradation }\end{array}$ \\
\hline
\end{tabular}

EPOX

Since the reforming process is sensitive to the amount and supply of oxygen, it is feasible to achieve reformate compositions higher in hydrogen content if the oxygen needed can be metered in. This is especially true for the catalytic partial oxidation and autothermal reforming processes. Oxygen metering can be achieved either by partial pressure differential across a dense membrane made of oxygen/oxygen ion conducting materials (for example, perovskites) or by using electrochemical driving force. By operating the fuel processor as an electrochemical cell with air on the cathode side and fuel on the anode side, oxygen can be metered in across electrolyte or mixed ion conducting membranes by controlling the current density, temperature and feed flow rates.

An EPOX fuel processor has higher subsystem complexity and poses challenges in control and regulation of operating parameters. In addition, EPOX may involve additional penalties such as parasitic power draw, mechanical stability etc. On the positive side, it can be envisioned that much lesser number of parts and need for external pumping requirements, which will lighten the load on the system. A system level trade-off analysis of the benefits accrued through the enhanced concentration of the reformate versus the power draw requirements and need for control systems can help in assessing if there is a net gain for the EPOX process for reforming fuels for the SOFC. The advantages and disadvantages of EPOX are shown in Table 6.

Table 6. EPOX Advantages and Disadvantages

\begin{tabular}{|l|l|l|}
\hline Characteristic & Advantage & Disadvantage \\
\hline Hydrogen Yield & $\begin{array}{l}\text { Higher yields possible, } \\
\text { since nitrogen dilution is } \\
\text { minimized }\end{array}$ & * See notes below \\
\hline Heat Requirement & & $\begin{array}{l}\text { May have excess net } \\
\text { heat if aiding a partial } \\
\text { oxidation reaction. } \\
\text { Controlling and } \\
\text { minimizing the } \\
\text { degradation of materials } \\
\text { at the higher } \\
\text { temperatures of }\end{array}$ \\
\hline
\end{tabular}




\begin{tabular}{|l|l|l|}
\hline & & operation is challenging \\
\hline Startup/Transients & $\begin{array}{l}\text { Startup can be very fast. } \\
\text { Transients and control } \\
\text { can be more accurate } \\
\text { since we now have an } \\
\text { electronic lever on } \\
\text { oxygen supply rate }\end{array}$ & \\
\hline
\end{tabular}

* Even the dilution of the reformate stream by minimizing the amount of nitrogen in the system flows is achieved (reformate flow into the SOFC fuel intake), elimination of the buffering effect of diluent could impact the system.

\section{Fuel Processor Technology Literature Survey}

To gather further information about the different fuel processor technologies, prior to conducting the QFD analysis, a literature survey was conducted. A summary of the literature survey is presented Tables 7 through 9 . This literature survey, although not claiming to be all encompassing, highlights the current state of the art in the technologies under consideration. It also garners specific citations of data on the operating parameters for each of the technologies. A short description of the content of each literature citation is presented.

Table 7 Steam Reforming Literature Search Summary

\begin{tabular}{|c|c|c|c|}
\hline Source & Title & Abstract & Author \\
\hline $\begin{array}{l}\text { Appl. Catal. A: } \\
136 \text { (1996), } 49\end{array}$ & $\begin{array}{l}\text { Development of highly } \\
\text { stable nickel catalyst for } \\
\text { methane-steam reaction } \\
\text { under low steam to } \\
\text { carbon ratio }\end{array}$ & $\begin{array}{l}\mathrm{Ni}-\mathrm{Mg}-\mathrm{O} \text { type catalyst } \\
\text { demonstrated higher activity and } \\
\text { selectivity comparing with } \\
\mathrm{Ni} / \mathrm{A}_{12} \mathrm{O}_{3}-\mathrm{MgO} \text { when properly } \\
\text { prepared. }\end{array}$ & $\begin{array}{l}\text { Yamazaki, } \\
\text { Tomishiige, Fujimoto } \\
\text { University of Tokoyo }\end{array}$ \\
\hline $\begin{array}{l}\text { J. Catal, } 124 \\
\text { (1990), } 324\end{array}$ & $\begin{array}{l}\text { Deactivation of steam- } \\
\text { reforming model catalysts } \\
\text { by coke formation }\end{array}$ & $\begin{array}{l}\text { Coke formation in the } \\
\text { hydrogenolysis of cyclopentane } \\
\text { on } \mathrm{Ni} / \mathrm{Al}_{2} \mathrm{O}_{3} \text { catalysts in } 300 \text { to } \\
500 \mathrm{C} \text { studied }\end{array}$ & $\begin{array}{l}\text { Duprez, et. al. } \\
\text { Laboratoire de } \\
\text { Catalyse en Chimie } \\
\text { Organique, }\end{array}$ \\
\hline $\begin{array}{l}\text { Catal. Lett, } 32 \\
\text { (1995) } 387\end{array}$ & $\begin{array}{l}\text { Large enhancement in } \\
\text { methane-to-syngas } \\
\text { conversion activity of } \\
\text { supported Ni catalysts } \\
\text { due to precoating of } \\
\text { catalyst support with } \\
\text { MgO, CaO or rare-earth } \\
\text { oxide }\end{array}$ & $\begin{array}{l}\text { Coating of } \mathrm{MgO} \text { and } \mathrm{CaO} \text { over } \\
\mathrm{SiO}_{2} \text { or } \mathrm{Al}_{2} \mathrm{O}_{3} \text { improves steam } \\
\text { reforming catalyst activity and } \\
\text { selectivity. } \mathrm{MgO} \text { is better coating } \\
\text { material. }\end{array}$ & $\begin{array}{l}\text { V. R. Choudhary, B. } \\
\text { S. Uphade and A. S. } \\
\text { Mamman, National } \\
\text { Chemical Lab, India }\end{array}$ \\
\hline $\begin{array}{l}\text { PCT Int. Appl. } \\
\text { (2001), }\end{array}$ & $\begin{array}{l}\text { Fuel supply to a fuel cell } \\
\text { system. }\end{array}$ & $\begin{array}{l}\text { A process for producing electricity } \\
\text { in a fuel cell comprises reacting a } \\
\text { higher carbon }(\mathrm{C} 2+) \text { hydrocarbon } \\
\text { fuel with steam in a steam pre- } \\
\text { reformer at a temp. in the pre- } \\
\text { reformer of no greater than } 500^{\circ}\end{array}$ & $\begin{array}{l}\text { Foger, Karl; Ahmed, } \\
\text { Khaliq. (Ceramic } \\
\text { Fuel Cells Limited, } \\
\text { Australia). }\end{array}$ \\
\hline US $6162267 \mathrm{~A}$ & Process for the & The hydrogen product stream is & Priegnitz, James W.; \\
\hline
\end{tabular}




\begin{tabular}{|c|c|c|c|}
\hline & $\begin{array}{l}\text { generation of pure } \\
\text { hydrogen for use with fuel } \\
\text { cells. }\end{array}$ & $\begin{array}{l}\text { produced from the feed stream in } \\
\text { a novel steam reforming zone } \\
\text { containing a steam reforming } \\
\text { catalyst disposed in a bell-shaped } \\
\text { catalyst zone. The bell-shaped } \\
\text { catalyst zone is disposed over a } \\
\text { combustion zone such that the } \\
\text { exhaust gas from the combustion } \\
\text { flows around the bell-shaped } \\
\text { catalyst zone to heat the catalyst } \\
\text { from the inside and the outside of } \\
\text { the catalyst zone. ... }\end{array}$ & $\begin{array}{l}\text { Oroskar, Anil R.; } \\
\text { Stippich, Kenneth J., } \\
\text { Jr.; Towler, Gavin P.; } \\
\text { Bussche, Kurt } \\
\text { Vanden. (UOP LLC, } \\
\text { USA). }\end{array}$ \\
\hline $\begin{array}{l}\text { PCT Int. Appl. } \\
\text { (2000), WO } \\
0016900 \text { A1 }\end{array}$ & $\begin{array}{l}\text { Catalysts and process for } \\
\text { steam reforming of } \\
\text { hydrocarbons. }\end{array}$ & $\begin{array}{l}\text { The present invention is directed } \\
\text { to catalysts for the production of a } \\
\text { mixture of hydrogen and carbon } \\
\text { monoxide by steam reforming of a } \\
\text { hydrocarbon feedstock as well as } \\
\text { to precursors of such catalysts. } \\
\text { The catalyst precursors include a } \\
\text { mixture of nickel oxide and an } \\
\text { oxide of cubic structural type } \\
\text { which is an oxygen ion conductor } \\
\text { at elevated temps... }\end{array}$ & $\begin{array}{l}\text { Millar, Graeme John; } \\
\text { Gamman, Jonathan } \\
\text { James. (The } \\
\text { University of } \\
\text { Queensland, } \\
\text { Australia). }\end{array}$ \\
\hline $\begin{array}{l}\text { PCT Int. Appl. } \\
\text { (1999), WO } \\
9935082 \text { A1 }\end{array}$ & $\begin{array}{l}\text { Control of hydrogen and } \\
\text { carbon monoxide } \\
\text { produced in partial } \\
\text { oxidation process. }\end{array}$ & $\begin{array}{l}\text { A process is described for } \\
\text { enhancing } \mathrm{H} 2 \text { or } \mathrm{CO} \text { production } \\
\text { in a partial oxidation. reaction by } \\
\text { feeding } \mathrm{H} 2 \mathrm{O} \text { or } \mathrm{CO} 2 \text { with the feed } \\
\text { hydrocarbon and oxygen over a } \\
\text { transition metal monolith catalyst } \\
\text { such as unsupported Ni monolith } \\
\text { or alternatively contacting the } \\
\text { hydrocarbon/oxygen first with a } \\
\text { noble metal then with a transition } \\
\text { metal with the } \mathrm{H} 2 \mathrm{O} \text { or } \mathrm{CO} 2 \text { being } \\
\text { added before or after the noble } \\
\text { metal catalyst.... }\end{array}$ & $\begin{array}{l}\text { Schmidt, Lanny D.; } \\
\text { Witt, Paul M. } \\
\text { (Regents of the } \\
\text { University of } \\
\text { Minnesota, USA). }\end{array}$ \\
\hline $\begin{array}{l}\text { Jpn. Kokai } \\
\text { Tokkyo Koho } \\
\text { (1998), JP } \\
10052639 \text { A2 } \\
19980224 \\
\text { Heisei }\end{array}$ & $\begin{array}{l}\text { Ruthenium-loaded } \\
\text { alumina catalyst for } \\
\text { steam reforming of } \\
\text { hydrocarbons in } \\
\text { hydrogen production. }\end{array}$ & $\begin{array}{l}\text { The title catalyst comprises Ru } \\
0.05-5, \mathrm{ZrO} 0.05-20 \text {, and } \mathrm{Mg} \text { or } \\
\text { Co } 0.05-20 \text { wt. } \% \text { on a porous } \\
\text { alumina support and has a sp. } \\
\text { surface area ( } \mathrm{S} 1 \text { ) of } 8-50 \mathrm{~m}^{2} / \mathrm{g} \text {. } \\
\text { The porous alumina support has } \\
\text { a pore vol. of } 0.05-0.5 \mathrm{~cm}^{3} / \mathrm{g} \text {, an } \\
\text { av. pore diameter. of } 0.01-100 \\
\mathrm{~m} \text {, and a sp. surface area (S2) } \\
\text { of } 0.05 \mathrm{~m}^{2} / \mathrm{g} \text {, but the } \mathrm{S} 2 / \mathrm{S} 1 \text { ratio } \\
\text { (3-50): } 1 \text {. The catalyst is durable } \\
\text { and effective for steam reforming } \\
\text { of lower hydrocarbons to produce } \\
\mathrm{H} 2 \text { for fuel cells. }\end{array}$ & $\begin{array}{l}\text { Maeno, Hironobu; } \\
\text { Matsumoto, Hiroto. } \\
\text { (Idemitsu Kosan Co., } \\
\text { Ltd., Japan). }\end{array}$ \\
\hline $\begin{array}{l}\text { Jpn. Kokai } \\
\text { Tokkyo Koho } \\
\text { (1996), JP } \\
08217403 \text { A2 } \\
19960827 \\
\text { Heisei. }\end{array}$ & $\begin{array}{l}\text { Catalytic steam reformer } \\
\text { for producing hydrogen- } \\
\text { rich gases in fuel cells. }\end{array}$ & $\begin{array}{l}\text { The title reformer includes } \\
\text { reforming pipes filled with two } \\
\text { layers of catalyst: (1) noble metal } \\
\text { catalyst (e.g., Ru) near inlet of } \\
\text { pipes and (2) normal metal } \\
\text { catalyst (e.g., Ni) near outlet of }\end{array}$ & $\begin{array}{l}\text { Take, Tetsuo; Kimata, } \\
\text { Katsuhisa. (Nippon } \\
\text { Telegraph \& } \\
\text { Telephone, Japan). }\end{array}$ \\
\hline
\end{tabular}




\begin{tabular}{|c|c|c|c|}
\hline & & $\begin{array}{l}\text { the pipes to prevent carbon } \\
\text { deposit and suppress methane } \\
\text { formation. }\end{array}$ & \\
\hline $\begin{array}{l}\text { Eur. Pat. Appl. } \\
\text { (1992), EP } \\
\text { 470626 A1 } \\
19920212\end{array}$ & $\begin{array}{l}\text { Catalyst for steam } \\
\text { reforming of } \\
\text { hydrocarbons. }\end{array}$ & $\begin{array}{l}\text { The catalyst comprises } \mathrm{Ni} \text { as } \\
\text { main catalytic component } \\
\text { supported on a refractory carrier } \\
\text { (e.g., alumina) with promoter } \\
\text { containing metal selected from } \\
\text { Group IVA and VA metals (e.g., } \\
\text { Sn). The catalyst is suitable for } \\
\text { production of } \mathrm{H} \text { and/or CO rich } \\
\text { gases by steam reforming of } \\
\text { hydrocarbon. }\end{array}$ & $\begin{array}{l}\text { Ul-Haque, Israr; } \\
\text { Trimm, David L. } \\
\text { (Haldor Topsoe A/S, } \\
\text { Den.). }\end{array}$ \\
\hline $\begin{array}{l}\text { Eur. Pat. Appl. } \\
\text { (1991), } \\
\text { EP 440258 A2 } \\
19910807\end{array}$ & $\begin{array}{l}\text { Heat exchange reforming } \\
\text { process and reactor } \\
\text { system. }\end{array}$ & $\begin{array}{l}\text { A catalytic process for steam } \\
\text { reforming of hydrocarbons is } \\
\text { described that heat from a } \\
\text { product stream of reformed gas is } \\
\text { utilized to supply heat required for } \\
\text { the endothermic reforming } \\
\text { reactions in a process gas of } \\
\text { hydrocarbons and steam by } \\
\text { indirect heat exchange between } \\
\text { the product gas and process gas. } \\
\text { The process is esp. suitable for } \\
\text { steam reforming of methane to } \\
\text { manufacture synthesis gas for } \\
\text { ammonia production }\end{array}$ & $\begin{array}{l}\text { Norsk, Jesper. } \\
\text { (Haldor Topsoe A/S, } \\
\text { Den.). }\end{array}$ \\
\hline
\end{tabular}

Table 8 ATR Literature Search Summary

\begin{tabular}{|c|c|c|c|}
\hline Source & Title & Abstract & Author \\
\hline $\begin{array}{l}\text { US Patent } \\
6,110,615\end{array}$ & $\begin{array}{l}\text { Fuel cell power plant with } \\
\text { electrochemical } \\
\text { autothermal reformer }\end{array}$ & $\begin{array}{l}\text { Mixed ion conductor membrane- } \\
\text { Purpose of the membrane is for } \\
\text { selective removal of hydrogen }\end{array}$ & $\begin{array}{l}\text { Niagara Mohawk } \\
\text { Power corporation } \\
\text { (Bloomfield, David) }\end{array}$ \\
\hline US $5,976,724$ & Same & $\begin{array}{l}\text { Heat exchanger and carrier gas } \\
\text { on top of a hydrogen selective } \\
\text { membrane }\end{array}$ & $\begin{array}{l}\text { Same company and } \\
\text { same authors }\end{array}$ \\
\hline EP 112613 & & $\begin{array}{l}\text { POX catalyst is } \mathrm{Pd} \text {, or } \mathrm{Pt} \text {. } \\
\text { Reforming cat zone is } \mathrm{Pt} \text { group } \\
\text { metal steam reforming cat. } \\
\text { Preheat temp } 427-720^{\circ} \mathrm{C} \text {, Temp } \\
\text { at exit of } 2^{\text {nd }} \text { zone is } 954^{\circ} \mathrm{C} \text {. } \\
\text { Steam and } \mathrm{CO}_{2} \text { are added to } \\
\text { POX zone. }\end{array}$ & \\
\hline EP 367654 & & $\begin{array}{l}\text { First step POX with } 50 \% \text { of } \\
\text { stoichiometric oxygen and steam } \\
\text { at less than } 1.5 \text { mole steam per } \\
\text { carbon atom. } \\
\text { Second step is contact with } \\
\text { Group VI or VIII metal . Temp } \\
\text { range in second step is } 800 \text { - } \\
1800^{\circ} \mathrm{C} \text {. }\end{array}$ & \\
\hline
\end{tabular}




\begin{tabular}{|c|c|c|c|}
\hline & & $\begin{array}{l}\text { Second step supposed to reduce } \\
\text { soot formed in first step }\end{array}$ & \\
\hline $\begin{array}{l}\text { Hydrocarbon } \\
\text { Processing, } \\
\text { March 1994, } \\
\text { Pages 39-46 }\end{array}$ & $\begin{array}{l}\text { Commercial Autothermal } \\
\text { reforming difficulties.. }\end{array}$ & $\begin{array}{l}\text { Syngas with hydrogen to Carbon } \\
\text { monoxide molar ratio } 2 \text { in product. } \\
\mathrm{CO}_{2} \text { addition is required. and } \mathrm{H}_{2} \mathrm{O} \\
\text { Molar addition should be low but } \\
\text { more than } 0.5 \text {, about } 0.6 ; \mathrm{CO}_{2} / \mathrm{C} \\
\text { molar ratio is typically form } 0.3 \text { to } \\
0.5\end{array}$ & $\begin{array}{l}\text { Christensen and } \\
\text { Primdahl }\end{array}$ \\
\hline US $6,207,078$ & $\begin{array}{l}\text { Process for production of } \\
\text { Synthesis gas }\end{array}$ & $\begin{array}{l}\text { First is primary reforming section } \\
\text { where } \mathrm{HC} \text { and steam are first } \\
\text { contacted. Oxygen introduced in } \\
\text { second reforming section. - ATR } \\
\text { Section is a part of the flow } \\
\text { system. }\end{array}$ & $\begin{array}{l}\text { Ammonia Casale SA } \\
\text { ( Badano, March } \\
\text { 2001) }\end{array}$ \\
\hline $\begin{array}{l}\text { US 5,799,482 } \\
\text { And US } \\
6,025,403\end{array}$ & $\begin{array}{l}\text { Process for improved } \\
\text { heat integration of an } \\
\text { oxidant-supplemented } \\
\text { autothermal reformer and } \\
\text { cogen power plant }\end{array}$ & $\begin{array}{l}2 \text { fluidized beds in reforming unit, } \\
\text { inorganic metal oxide used in } \\
\text { ATR in first bed is regenerated in } \\
\text { second bed.- integration portion is } \\
\text { about compressed air drawn off } \\
\text { from the power plant gas turbine } \\
\text { air compressor. Also, hot flue gas } \\
\text { from regenerator is fed to } \\
\text { combustor of cogen plant. }\end{array}$ & $\begin{array}{l}\text { Mobil Oil Corp } \\
\text { (Marler et al, Sep } \\
1998 \text { and Feb 2000) }\end{array}$ \\
\hline $\begin{array}{l}\text { US } 864230 \\
20010525 \\
\text { JP } \\
\text { P2000165098 } \\
20000601\end{array}$ & Reforming Apparatus & $\begin{array}{l}\text { Steam reforming and POX, uses } \\
\text { heat from POX for steam } \\
\text { reforming. POX upstream from } \\
\text { steam reforming. Oxidizer control } \\
\text { for selective oxidation on POX., } \\
\text { Steam fed to box POX and steam } \\
\text { reforming., with master control } \\
\text { that allows for steam only to } \\
\text { steam reforming during transients } \\
\text { and Startup }\end{array}$ & $\begin{array}{l}\text { Nissan Motor Co. Ltd } \\
\text { (Hiroyuki Ichikawa et } \\
\text { al) }\end{array}$ \\
\hline $\begin{array}{l}\text { DOE Annual } \\
\text { Laboratory } \\
\text { Reviews }\end{array}$ & $\begin{array}{l}\text { Catalytic Autothermal } \\
\text { Reforming }\end{array}$ & $\begin{array}{l}\text { Ru/Palladium better than Pt for } \\
\text { ATR. } 100 \% \text { conversion above } \\
650^{\circ} \mathrm{C} \mathrm{Ce} \text {. } \mathrm{Zr} \text {, Lanthanum Gallate } \\
\text { as substrates. } 50 \% \mathrm{H}_{2} \text { yield before } \\
\text { water gas shift (WGS), } 65 \% \text { after } \\
\text { WGS stage. }\end{array}$ & $\begin{array}{l}\text { Argonne National } \\
\text { Lab., Krumpelt, } \\
\text { Ahmed et al. }\end{array}$ \\
\hline US 5,628,931 & $\begin{array}{l}\text { Process for preparation of } \\
\text { hydrogen and CO } \\
\text { containing mixtures. }\end{array}$ & $\begin{array}{l}\text { ATR - POX followed by "reforming } \\
\text { zone", POX at } \mathrm{H}_{2} \mathrm{O}: \mathrm{C} \text { of less than } \\
0.2 \text { or less than } 0.5 \text { and reformed } \\
\text { product stream at temp } 1000^{\circ} \mathrm{C} \text { - } \\
1350^{\circ} \mathrm{C} \text {, or } 1300^{\circ} \mathrm{C} \text {, and } \mathrm{POX} \text { is } \\
\text { at } \mathrm{H}_{2} \mathrm{O}: \mathrm{C} \text { of less than } 0.1 \text {. } \\
\text { Low } \mathrm{H}_{2} \mathrm{O} / \mathrm{C} \text { molar ratio and/or a } \\
\text { relatively high reformed product } \\
\text { stream temperature soot } \\
\text { formation is negligible. } \\
\text { POX is with a burner, a co- } \\
\text { annular type burner, no catalyst }\end{array}$ & $\begin{array}{l}\text { Shell Oil Company } \\
\text { (Lednor, May 1997) }\end{array}$ \\
\hline
\end{tabular}




\begin{tabular}{|l|l|l|}
\hline & $\begin{array}{l}\text { Catalysts in reforming zone : one } \\
\text { or more of group VIII or nickel.( Pt } \\
\text { in Group VIII or in combination } \\
\text { with Rhodium or Lanthanum and } \\
\text { Cerium). Support is alpha } \\
\text { aluminas, hexa aluminates and } \\
\text { silica. }\end{array}$ \\
$\begin{array}{l}\text { Cat preparation: calcination in } \\
\text { excess oxygen at } 450-600^{\circ} \mathrm{C} \\
\text { (noble metal } 0.4-8 \% \text { non-noble } \\
\text { group VIII form } 1 \text { to } 40 \% \text { by wt., } \\
\text { preferably } 5 \text { to } 30 \% \text { by weight } \\
\text { based on the total catalyst. }\end{array}$ \\
\hline
\end{tabular}

Table 9 CPOX Literature Search Summary

\begin{tabular}{|c|c|c|c|}
\hline Source & Title & Abstract & Author \\
\hline $\begin{array}{l}\text { EP1134188 } \\
(2001)\end{array}$ & $\begin{array}{l}\text { Catalytic partial oxidation } \\
\text { of hydrocarbons }\end{array}$ & $\begin{array}{l}\text { Hydrocarbons are partially } \\
\text { oxidized to form a gas mixture } \\
\text { comprising carbon monoxide and } \\
\text { hydrogen. A mixture of a } \\
\text { hydrocarbon containing gas and } \\
\text { an oxygen-containing gas is } \\
\text { contacted with a catalytically } \\
\text { effective amount of a reduced } \\
\text { metal catalyst consisting } \\
\text { genetically of a transition or noble } \\
\text { metal selected from nickel, cobalt, } \\
\text { iron, platinum, palladium, iridium, } \\
\text { rhenium, ruthenium, monolith } \\
\text { substrate under conditions that } \\
\text { initiate the partial oxidation } \\
\text { reaction. The reaction can be } \\
\text { initiated at a temperature of less } \\
\text { than } 200^{\circ} \mathrm{C} \text {. }\end{array}$ & $\begin{array}{l}\text { R. Narayanan, et. al, } \\
\text { BOC Group Inc. (US) }\end{array}$ \\
\hline $\begin{array}{l}\text { WO 0000425 } \\
(2000)\end{array}$ & $\begin{array}{l}\text { Catalytic partial oxidation } \\
\text { with two catalytically- } \\
\text { active metals }\end{array}$ & $\begin{array}{l}\text { The invention relates to a catalyst } \\
\text { or a precursor thereof in the form } \\
\text { of a fixed arrangement or in the } \\
\text { form of catalyst (precursor) } \\
\text { particles, wherein the fixed } \\
\text { arrangement or the particles } \\
\text { comprise(s) at least two layers, } \\
\text { the first layer comprising as a } \\
\text { catalytically active metal or } \\
\text { precursor thereof rhodium or a } \\
\text { rhodium compound and the } \\
\text { second layer comprising as a }\end{array}$ & $\begin{array}{l}\text { K. G. Jan, et. Al, Shell } \\
\text { Int. Research (NL) }\end{array}$ \\
\hline
\end{tabular}




\begin{tabular}{|c|c|c|c|}
\hline & & $\begin{array}{l}\text { catalytically active metal or } \\
\text { precursor thereof iridium, osmium } \\
\text { or platinum or a compound } \\
\text { thereof. The invention further } \\
\text { relates to the use of the catalyst, } \\
\text { especially in a process for the } \\
\text { catalytic partial oxidation of a } \\
\text { hydrocarbonaceous feedstock. }\end{array}$ & \\
\hline $\begin{array}{l}\text { EP 1043271 } \\
(2000)\end{array}$ & $\begin{array}{l}\text { Apparatus for the } \\
\text { catalytic partial oxidation } \\
\text { of hydrocarbons }\end{array}$ & $\begin{array}{l}\text { The invention related to an } \\
\text { apparatus suitable for the } \\
\text { catalytic partial oxidation of a } \\
\text { hydrocarbonaceous feedstock, } \\
\text { comprising a synthesis gas } \\
\text { collection vessel (1), and a } \\
\text { manifold of reactors (5) each } \\
\text { comprising a mixer and a catalyst } \\
\text { bed suitable for the partial } \\
\text { oxidation, wherein the reactors } \\
\text { are substantially vertically } \\
\text { mounted on the synthesis gas } \\
\text { collection vessel with the mixer } \\
\text { above the catalyst bed, and to a } \\
\text { catalytic partial oxidation process } \\
\text { using such an apparatus. }\end{array}$ & $\begin{array}{l}\text { W. H. Martinus, Shell } \\
\text { Int. Research (NL) }\end{array}$ \\
\hline $\begin{array}{l}\text { Catal. Today } \\
63 \text { (2000), } 489\end{array}$ & $\begin{array}{l}\text { Partial oxidation of } \\
\text { methane to synthesis } \\
\text { gas: Elimination of gas } \\
\text { phase oxygen }\end{array}$ & $\begin{array}{l}\text { The reaction between methane } \\
\text { and cerium oxide to produce } \\
\text { syngas has been studied at } 700^{\circ} \mathrm{C} \\
\text { in a pulse apparatus. The cerium } \\
\text { oxide was supported on } \mathrm{Al}_{2} \mathrm{O}_{3} \\
\text { and promoted by re-impregnation } \\
\text { with Pt or Rh. The promoters } \\
\text { drastically enhanced the } \\
\text { conversion of methane. TPR with } \\
\text { hydrogen shows that Pt and Rh } \\
\text { also lowered the temperature } \\
\text { necessary to reduce the cerium } \\
\text { oxide. Studies of the reaction } \\
\text { between methane and promoted } \\
\text { cerium oxide showed that the } \\
\text { selectivity to syngas depends on } \\
\text { the degree of reduction of the } \\
\text { cerium oxide. The promoters also } \\
\text { led to some carbon formation. } \\
\text { Regeneration of the reduced } \\
\text { oxide was studied both with } \\
\text { oxygen and carbon dioxide. } \odot \\
2000 \text { Elsevier Science B.V. All } \\
\text { rights reserved. }\end{array}$ & $\begin{array}{l}\text { M. Fathi, et. al., } \\
\text { Norwegian U. of Sci. } \\
\text { and Tech. (Norway) }\end{array}$ \\
\hline $\begin{array}{l}\text { WO 9948805 } \\
\text { (1999) }\end{array}$ & $\begin{array}{l}\text { Catalytic Generation of } \\
\text { Hydrogen }\end{array}$ & $\begin{array}{l}\text { A process for the catalytic } \\
\text { generation of hydrogen by the } \\
\text { self-sustaining combination of } \\
\text { partial oxidation and steam } \\
\text { reforming of a hydrocarbon } \\
\text { comprises contacting a mixture of } \\
\text { the hydrocarbon, an oxygen- } \\
\text { containing gas and steam with a }\end{array}$ & $\begin{array}{l}\text { C. I. William, et al., } \\
\text { Johnson Matthey (GB) }\end{array}$ \\
\hline
\end{tabular}




\begin{tabular}{|c|c|c|c|}
\hline & & $\begin{array}{l}\text { catalyst comprising rhodium } \\
\text { dispersed on a refractory oxide } \\
\text { support material which is mixture } \\
\text { of ceria and zirconia. The } \\
\text { hydrocarbons are straight chain } \\
\text { or branch chain hydrocarbons } \\
\text { having } 1 \text { to } 15 \text { carbon atoms and } \\
\text { include methane, propane } \\
\text { butane, hexane, heptane, normal- } \\
\text { octane, iso-octane, naphthas, } \\
\text { liquefied petroleum gas and } \\
\text { reformulated gasoline petrol and } \\
\text { diesel fuels. The hydrogen } \\
\text { generation process can be } \\
\text { started by feeding the } \\
\text { hydrocarbon and air to initiate } \\
\text { partial oxidation, before steam is } \\
\text { added. The hydrogen generation } \\
\text { process also may be operated in } \\
\text { combination with a water-gas shift } \\
\text { reaction for the reduction of } \\
\text { carbon monoxide in the hydrogen } \\
\text { generated. }\end{array}$ & \\
\hline $\begin{array}{l}\text { Energy Fuels } \\
(2001), 15(6)\end{array}$ & $\begin{array}{l}\text { Hydrogen production by } \\
\text { catalytic decomposition of } \\
\text { methane }\end{array}$ & $\begin{array}{l}\text { Traditionally, hydrogen is } \\
\text { produced by reforming or partial } \\
\text { oxidation of methane to produce } \\
\text { synthesis gas, followed by the } \\
\text { water-gas shift reaction to convert } \\
\text { CO to CO2 and produce more } \\
\text { hydrogen, followed in turn by a } \\
\text { purification or separation } \\
\text { procedure. This paper presents } \\
\text { results for the catalytic } \\
\text { decomposition of undiluted } \\
\text { methane into hydrogen can } \\
\text { carbon using nanoscale, binary, } \\
\text { FE-M (M=Pd, Mo, or Ni) catalyst } \\
\text { supported on alumina. All of the } \\
\text { supported Fe-M binary catalyst } \\
\text { reduced methane decomposition } \\
\text { temperature by } 400-500 \mathrm{C} \\
\text { relative to noncatalytic thermal } \\
\text { decomposition and exhibit } \\
\text { significantly higher activity than } \\
\text { Fe or any of the secondary metals } \\
\text { (Pd, Mo, and Ni) supported on } \\
\text { alumina alone. At reaction temps } \\
\text { of approx. } 700-800^{\circ} \mathrm{C} \text { and space } \\
\text { velocities of } 600 \text { mL g-1 h-1, the } \\
\text { product stream was comprised of } \\
\text { over } 80 \text { vol. \% of hydrogen, with } \\
\text { the balance being unconverted } \\
\text { methane. No CO, CO2 or } \mathrm{C} 2 \text { and } \\
\text { higher hydrocarbons were } \\
\text { observed in the product gas. } \\
\text { High-resolution. Scanning }\end{array}$ & $\begin{array}{l}\text { N. Shah, et. al., U. of } \\
\text { Kentucky (USA) }\end{array}$ \\
\hline
\end{tabular}




\begin{tabular}{|c|c|c|c|}
\hline & & $\begin{array}{l}\text { Electron Microscope (SEM) and } \\
\text { Transmission Electron } \\
\text { Microscope (TEM) } \\
\text { characterization indicated that } \\
\text { almost all carbon produced in the } \\
\text { temperature range of } 700-800{ }^{\circ} \mathrm{C} \\
\text { is the form of potentially useful } \\
\text { multiwalled nanotubes. At higher } \\
\text { temps. }\left(>900^{\circ} \mathrm{C}\right) \text {, hydrogen } \\
\text { production Decreases and carbon } \\
\text { is deposited on the catalyst in the } \\
\text { form of amorphous carbon, } \\
\text { carbon flakes, and carbon fibers. } \\
\text { In the noncatalytic thermal } \\
\text { decomposition. Mode, at temps. } \\
\text { above } 900^{\circ} \mathrm{C} \text {, graphitic carbon } \\
\text { film is deposited everywhere in } \\
\text { the reactor. Thus, the morphol. of } \\
\text { the carbon produced may be the } \\
\text { controlling parameter in catalytic } \\
\text { decomposition of methane. The } \\
\text { efficient removal of the carbon } \\
\text { from the catalyst surface in the } \\
\text { form of nanotubes may be the key } \\
\text { factor influencing catalyst } \\
\text { performance. }\end{array}$ & \\
\hline $\begin{array}{l}\text { Stud. Surf. Sci. } \\
\text { Catal. (2001), } \\
136(1-12)\end{array}$ & $\begin{array}{l}\text { Modeling millisecond } \\
\text { reactors }\end{array}$ & $\begin{array}{l}\text { Catalytic partial oxidation is a fast } \\
\text { reaction. The gradients in these } \\
\text { monolith reactors are typically } \\
106 \mathrm{~K} / \mathrm{s} \text { and } 105 \mathrm{~K} / \mathrm{cm} \text {. Detailed } \\
\text { modeling which includes detailed } \\
\text { descriptions of reactor geometry, } \\
\text { gas and solid properties, and } \\
\text { surface and homogeneous } \\
\text { reaction kinetics will be necessary } \\
\text { to develop reliable description of } \\
\text { these processes. }\end{array}$ & $\begin{array}{l}\text { Schmidt, L. D., U. of } \\
\text { Minnesota (USA). }\end{array}$ \\
\hline $\begin{array}{l}\text { Catal. Today } 69 \\
(2001), 131\end{array}$ & $\begin{array}{l}\text { Hurdles and solutions for } \\
\text { reactions between gas } \\
\text { and liquid in a monolithic } \\
\text { reactor }\end{array}$ & $\begin{array}{l}\text { In this paper, proof of principle } \\
\text { experiments and exploratory work } \\
\text { that solves the problem ensuring } \\
\text { that a gaseous and a liquid } \\
\text { reactant are available at the } \\
\text { catalytically active site at the } \\
\text { same time by separating the } \\
\text { reaction and the transport of the } \\
\text { gaseous reactant. The } \\
\text { equipment consisted of an } \\
\text { autoclave in which a feed was } \\
\text { saturated with hydrogen, a } \\
\text { reactor with a catalyst coated on } \\
\text { a monolith, a pump to circulate } \\
\text { the feed/product stream, and } \\
\text { devices to control and monitor the } \\
\text { process. } \\
\text { A lot of information of how to } \\
\text { process can be practiced was }\end{array}$ & $\begin{array}{l}\text { M. Vaarkamp, } \\
\text { Engelhard De Meern } \\
\text { (NL) }\end{array}$ \\
\hline
\end{tabular}




\begin{tabular}{|c|c|c|c|}
\hline & & $\begin{array}{l}\text { gathered during the work. } \\
\text { Conversion per pass should be } \\
\text { below the amount of hydrogen } \\
\text { that can be dissolved in the liquid } \\
\text { to avoid coke deposition (and } \\
\text { hence deactivation) of the } \\
\text { catalyst. The effectiveness of the } \\
\text { catalyst coated on the monolith } \\
\text { was found to be } 100^{\wedge} \text {. } \\
\text { Several variations of the process } \\
\text { design and catalysts used were } \\
\text { explored. Integration of the } \\
\text { monolith with a heat exchanger } \\
\text { will obviously allow for the use of } \\
\text { the process for very exothermic } \\
\text { reactions like (nitro) benzene } \\
\text { hydrogenation. A monolith to } \\
\text { which Rh-cyclooctadiene- } 1,2-b i s- \\
\text { diphenylfosfino-ethane (a } \\
\text { homogeneous catalyst) was } \\
\text { tethered was equally active in } \\
\text { hydrogenation of } 1 \text {-hexene as } \\
\text { Rh-cyclooctadiene- } 1,2-b i s- \\
\text { diphenylfosfino-ethane tethered } \\
\text { to a standard alumina. This } \\
\text { allows (fine) chemical producers } \\
\text { to repeatedly use the expensive } \\
\text { homogeneous catalysts without } \\
\text { the need for separation of the } \\
\text { catalyst from the reaction mixture. } \\
\text { ○ } 2001 \text { Elsevier Science B.V. All } \\
\text { rights reserved. }\end{array}$ & \\
\hline $\begin{array}{l}\text { J. of Catal. } 146 \\
(1994), 11\end{array}$ & $\begin{array}{l}\text { Synthesis gas formation } \\
\text { by catalytic oxidation of } \\
\text { methane in fluidized bed } \\
\text { reactors }\end{array}$ & $\begin{array}{l}\text { The production of synthesis gas } \\
\left(\mathrm{CO}+\mathrm{H}_{2}\right) \text { by the catalytic partial } \\
\text { oxidation of } \mathrm{CH}_{4} \text { in air or } \mathrm{O}_{2} \text { in } \\
\text { static fluidized beds at } \\
\text { atmospheric pressure has been } \\
\text { examined over } \mathrm{Pt}, \mathrm{Rh} \text {, and } \mathrm{Ni} \\
\text { catalysts coated on } 100-\mu \mathrm{m} \text { a-Al } \\
\mathrm{O}_{3} \text { beads. With } \mathrm{CH}_{4} / \text { air feeds, } \\
\mathrm{CO} \text { and } \mathrm{H}_{2} \text { selectivities as high as } \\
95 \% \text { with }>90 \% \mathrm{CH}_{4} \text { conversion } \\
\text { were obtained on } \mathrm{Rh} \text { and } \mathrm{Ni} \\
\text { catalysts at contact time of } 0.1- \\
0.5 \text { sec. } \mathrm{Pt} \text {. Catalysts were found } \\
\text { to have significantly lower } \\
\text { selectivities and conversions, } \\
\text { which may be due to more } \mathrm{H}_{2} \mathrm{O} \\
\text { forming reactions or the slow } \\
\text { steam reforming behavior of } \mathrm{Pt} \text {. } \\
\text { The optimal selectivities for all the } \\
\text { three catalysts were improved by } \\
\text { heating the reaction mixture } \\
\text { above the autothermal reactor } \\
\text { temperature and using } \mathrm{O}_{2} \\
\text { instead of air. The selectivities }\end{array}$ & $\begin{array}{l}\text { S. S. Bharadwaj and L. } \\
\text { D. Schmidt, U. of } \\
\text { Minnesota (USA) }\end{array}$ \\
\hline
\end{tabular}




\begin{tabular}{|c|c|c|c|}
\hline & & $\begin{array}{l}\text { and conversions were constant } \\
\text { over the range of contact times } \\
\text { used. Probable reaction } \\
\text { pathways for } \mathrm{CH}_{4} \text { oxidation in } \\
\text { fluidized beds are discussed. }\end{array}$ & \\
\hline $\begin{array}{l}\text { Catal. Let. } 75 \\
(2001), 13\end{array}$ & $\begin{array}{l}\text { Conversion of methane to } \\
\text { synthesis gas over } \\
\mathrm{Co} / \mathrm{Al} 2 \mathrm{O} 3 \text { by } \mathrm{CO} 2 \text { and/or } \\
\mathrm{O} 2\end{array}$ & $\begin{array}{l}\text { The } \mathrm{Y}-\mathrm{Al}_{2} \mathrm{O}_{3} \text { supported catalysts } \\
\text { were prepared by impregnating } \mathrm{Y}- \\
\mathrm{Al}_{2} \mathrm{O}_{3} \text { with aqueous solutions of } \\
\mathrm{Co}\left(\mathrm{NO}_{3}\right)_{2}-6 \mathrm{H}_{2} \mathrm{O} \text {, followed by } \\
\text { overnight drying at } 110^{\circ} \mathrm{C} \text { and } \\
\text { calcination in the open air of a } \\
\text { furnace of } 8 \mathrm{~h} \text { at various } \\
\text { temperatures ranging from } 500 \text { to } \\
1000^{\circ} \mathrm{C} \text {. The calcined catalysts } \\
\text { will be denoted as } \mathrm{Co}(\mathrm{O}) / \mathrm{Y}-\mathrm{Al}_{2} \mathrm{O}_{3} \\
(\mathrm{Tc}) \text {, the temperature inside the } \\
\text { parentheses indicating the } \\
\text { calcination temperature. The } \\
\text { catalysts reduced in } \mathrm{H}_{2} \text { will be } \\
\text { denoted as Co/ } \mathrm{Y}-\mathrm{Al}_{2} \mathrm{O}_{3} \text {. Co } \\
\text { loading means wt } \% \text { Co in the } \\
\text { completely reduced catalyst. }\end{array}$ & $\begin{array}{l}\text { H.Y. Wang and E. } \\
\text { Ruckenstein, State U. } \\
\text { of NY, (USA) }\end{array}$ \\
\hline
\end{tabular}

\section{Fuel Processor Technology Equilibrium Analysis}

To gain a further understanding of the different fuel processor product compositions, equilibrium analyses as temperature functions were conducted for the steam reforming, ATR, and CPOX technologies. These analyses were conducted with respect to natural gas and gasoline fuel types, and as functions of steam to carbon and oxygen to carbon ratios.

\section{QFD Analysis}

A QFD analysis was conducted to determine the fuel processor technology that would be most appropriate for the SECA program. Using the information obtained as part of the fuel processor system descriptions, their advantages and disadvantages, the literature survey, the product equilibrium analyses, and integrated system schematics, each technology was compared against a set of top level criteria. This criterion was derived from the DOE requirements for the SECA program and on critical parameters that effect the operation of the SOFC system. These parameters were weighted to recognize the relative importance of each of the requirements from the DOE's perspective. follows:

The criteria used for this fuel processor technology QFD are defined as

Power Rating: Can this technology give the required power of 3-10KW?

Turn Down Ratio: Ability of the system to operate from $0 \%$ to $100 \%$ power setting, in a steady-state mode, while maintaining performance (or within a tolerable level of under-performance) 
Scalability: Can the technology be scaled up from a lab set-up to the required kW level in a 3-4 year timeframe? Within the scope of the Phase I SECA program, assess how easy/difficult it would be to take developmental work into a demo unit.

Capital Cost: Best potential for low material cost.

Operating Cost: Cost of fuels, water, electricity, and raw materials.

Efficiency: LHV $\left(\mathrm{H}_{2}+\mathrm{CO}\right)$ / LHV (All Fuels)

Efficiency Degradation: No more than $\mathrm{x} \%$ over lifetime?.

Steady-State Test: Can the technology support demonstration test of 1500 hours (with minimal degradation of $\mathrm{x} \%$ )

Transient Test: Can the technology support test of 10 thermal cycles? No time limit for cycling. Thermal cycle is from "room Temperature" to "operating temperature"

Fuel Flexibility: Potential to operate with other fuels if add-ons are available. (The penalty for add-on requirements will be different for different technologies)

Tolerance to Fuel Impurities: Tolerance to particle waste such as sulfur and others with potential add-ons.(The 'penalty' for add-on requirements will be different for different technologies) (Different technologies may need add-ons for different input streams...)

Maintenance Intervals: Frequency should be no more frequent than 1000 operating hours.

Maintainability: Ease of performing maintenance functions. (How easy is it to access parts of the component for maintenance)

Maintenance Cost: Self-explanatory, lower maintenance cost is better.

Logistic Burden: (Taken from a military portability and logistics standpoint) What would one need readily on hand to support the system in the field?) (include cost of preparing/cleaning up the required inputs, fuel included )

Reliability (Fuel Processor System Complexity): Part count, etc.

Design Lifetime: To be designed for a lifetime of no less than 40,000 operating hours for stationary applications. 
Compact Size: Self-explanatory, smaller size is better. (No DOE requirement).

Integration Ease: Ease of system integration. Inclusive of thermal integration (heat loads)

Start-up time: Ease of start-up \& faster time. (Cold starts.), Faster considered better

Controllability: Ability to operate and control, including tolerance to variable fuel input levels. (Sensitivity to input fluctuations.)

Carbon Generation: Self-explanatory, less is better- How much is the propensity of each technology to generate carbon during operation/malfunction/hiccup.

Technology Maturity: Status of current technology with respect to program risk. With the current state of market expertise on each of the technologies, how do we foresee the impact on the overall program risk?

Potential Future Gains: (The flip side to Technology Maturity-will the technology be a good system solution once the technology has matured?) Is the technology likely to be scaleable? How big is the opportunity space for the said technology to blossom so as to be the "key" technology of the future?

The results of the fuel processor assessment suggested that, with the exception of EPOX, all of the other three technologies held almost equal promise in their potential for use with a $5 \mathrm{~kW}$ SOFC system. Each technology presents a feasible operating system, with efficiency gains in some being offset by additional needs for thermal, controls, size and system complexity. EPOX, on the other hand, was relatively nascent, but might present significantly higher gains.

Since one of the driving imperatives of the SECA program is to provide a low cost solution, a more thorough investigation of each technology's potential in terms of its ability to meet the system cost projections on a multi- unit manufacturing scale is necessary. As it stands, since the assessment is technology driven, to date, the cost issues have only been considered superficially in the QFD analysis. For example, in the QFD analysis, the cost related criteria were segregated as capital cost, operating cost and maintenance costs, and capital cost of the fuel processor sub component is recognized as having the biggest impact on the manufactured unit cost relative to operating and maintenance costs.

\section{Fuel Processor Laboratory Test Facility}

To enable the testing of fuel processor technologies up to $10 \mathrm{~kW}$ in size, an existing laboratory test facility was reactivated. As part of this activation process, the following tasks were accomplished: 
- Verified natural gas compressor operation

- Calibrated test cell carbon monoxide and combustible gas safety sensors

- Verified flare operation

- Verified test cell ventilation system operation

- Verified operation of the deionized water system

- Setup the gas chromatograph

- Setup the fuel processor product gas sampling system

- Checked out the fuel processor interface pressure and temperature sensors

Additional effort to optimize the performance of the gas chromatograph (GC) to enable quicker and more accurate analysis of natural gas and fuel processor streams is still required. The existing GC approach utilizes two columns in series, a silica gel and a molecular sieve $5 \mathrm{~A}$, in separate ovens. The sample gas is injected onto the silica gel column, where the heavier compounds are separated from the lighter ones. The lighter compounds then enter the molecular sieve $5 \mathrm{~A}$ column, where they are separated from one another. After the lighter compounds have been analyzed, the heavier compounds are separated from one another by temperature ramping the silica gel column.

Using this approach has yielded poor resolution of the methane and carbon monoxide peaks as shown in Figure 13, in addition to long sample process times. The resolution of the methane and carbon monoxide peaks was improved by relocating the molecular sieve $5 \mathrm{~A}$ column to the silica gel oven, reducing the initial oven temperature, and incorporating two different temperature ramps to elude the compounds. Figure 14 illustrates this improvement. Further effort to reduce the sample processing time is ongoing.

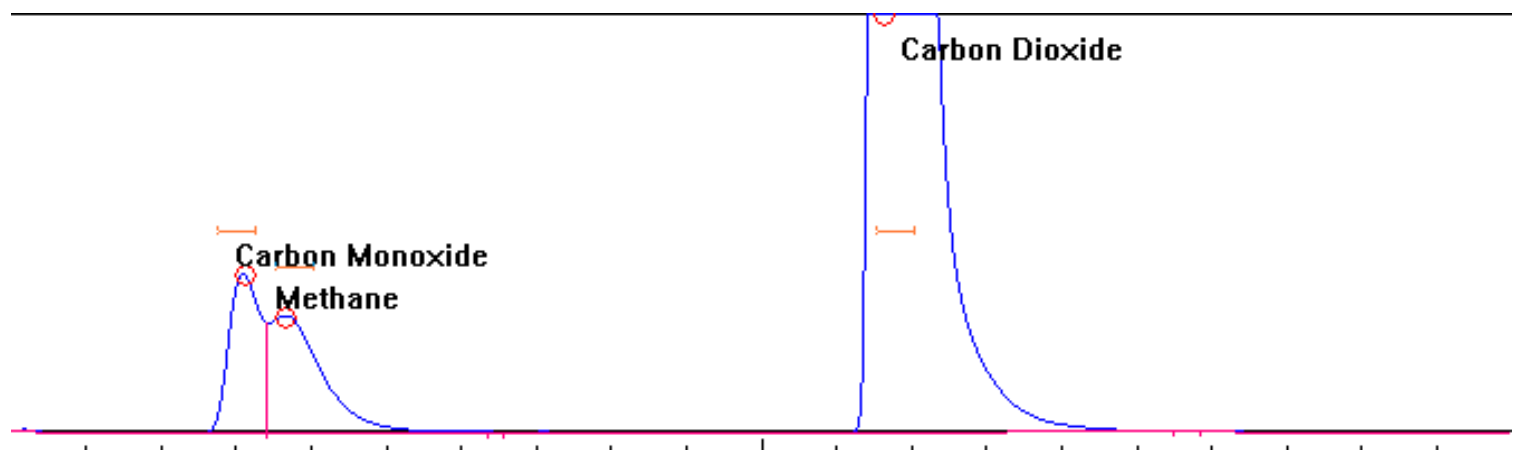

Figure 13. Initial GC Performance; Poor Carbon Monoxide and Methane Peak Resolution 


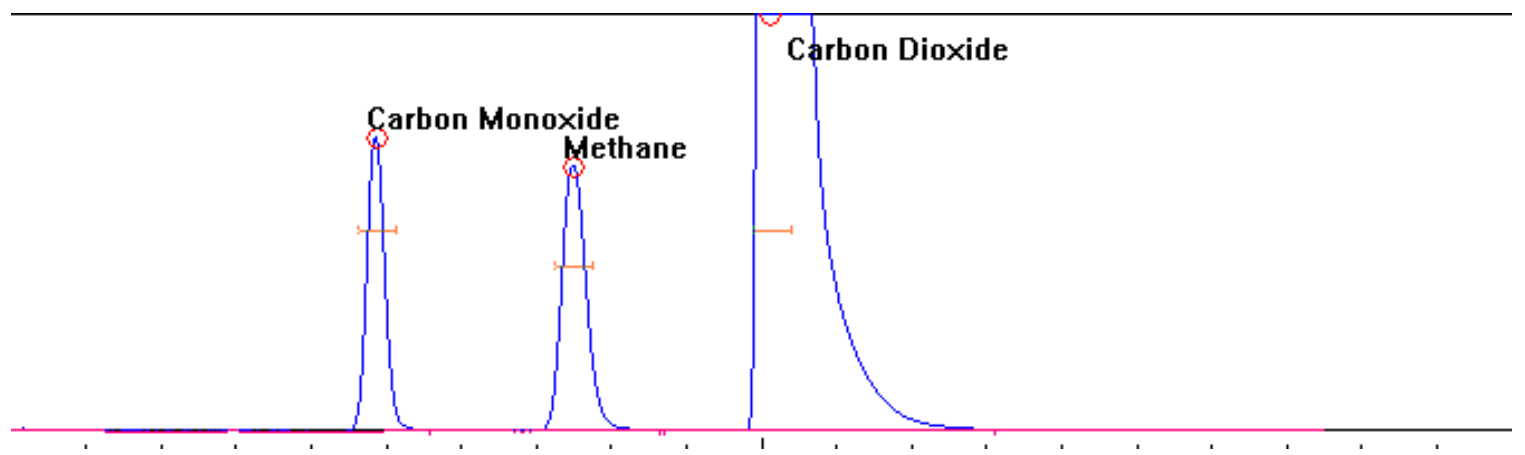

Figure 14. Improved GC Performance; Good Carbon Monoxide and Methane Peak Resolution

\section{2 $\underline{\text { CPOX/ATR Development }}$}

Based on the assessment of fuel processing technologies, the CPOX reformer was expanded to include the evaluation of autothermal reforming (ATR) and steam reforming. Autothermal reforming is a combination of partial oxidation and steam reforming. The technology utilizes the heat generated from CPOX to balance the heat needed for steam reforming which generates higher yield (more hydrogen).

\section{Experimental Set-ups}

To support the evaluation of three main reforming technologies (CPOX, autothermal reforming and steam reforming), experimental set-ups were designed for laboratory testing of all three technologies.

\section{$\underline{\text { Results }}$}

Extensive safety reviews were conducted on the experimental set-ups for evaluations of steam reforming and multi-fuel reformer. Both set-ups are ready for feasibility testing and optimization.

The small-scale CPOX set-up was modified to include both propane and methane. A quick test was conducted to see the effect of fuels (from propane to methane). Figure 15 is a plot of temperature profile for this test. 


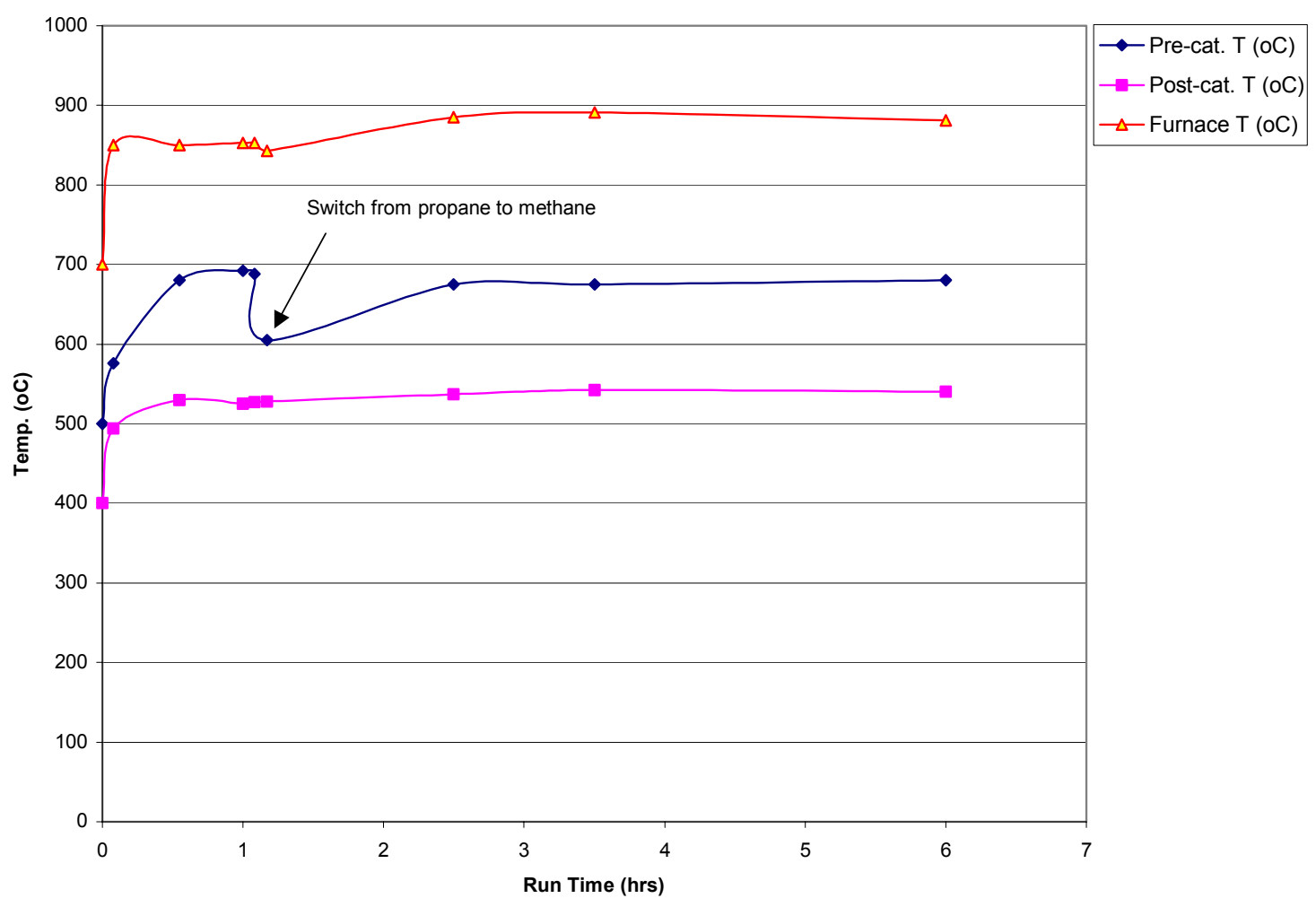

Figure 15. Temperature Profile of CPOX Test

\subsection{Internal Reforming}

Hydrogen, by far, is the most desirable fuel for the SOFC, but difficulties in both its manufacture and subsequent storage make it a poor choice for cost sensitive applications. As a result, efforts are being focused upon the use of more readily accessible fossil fuel-based materials to power SOFC's such as natural gas (methane), diesel, or gasoline.

In order to utilize hydrocarbon fuels like methane in the SOFC, the fuel must either be amenable to direct oxidation at the anode, or it must undergo reformation to form syngas (hydrogen and carbon monoxide). Without question, the direct oxidation of hydrocarbon fuels is a highly desirable process for the SOFC system in that it circumvents the need for the bulky fuel processing apparatus and thermodynamically inefficient fuel processing step. However, studies have shown that direct electrochemical oxidation of fuels like methane and ethane is much slower than the oxidation of hydrogen. Direct oxidation of hydrocarbons can lead to the formation of carbon at the active catalyst material comprising the SOFC anode, thereby rendering it ineffective.

Options available for the reformation of hydrocarbon fuels to form syngas include steam reforming, partial oxidation reformation, and autothermal reforming. As discussed earlier, steam reformation is particularly attractive for the SOFC application as the resulting processed fuel stream contains a 
significantly higher level of hydrogen for use in the fuel cell. However, steam reformation is an endothermic process requiring a continuous influx of heat from a suitable source to sustain the chemical oxidation reaction. One highly efficient solution to this problem is to locate the fuel processing step in close proximity to the SOFC stack in order to make use of the high heat of the SOFC. In this way, system efficiency losses due to inefficient heat transfer are minimized. This overall process is summarized in Figure 16 shown below.

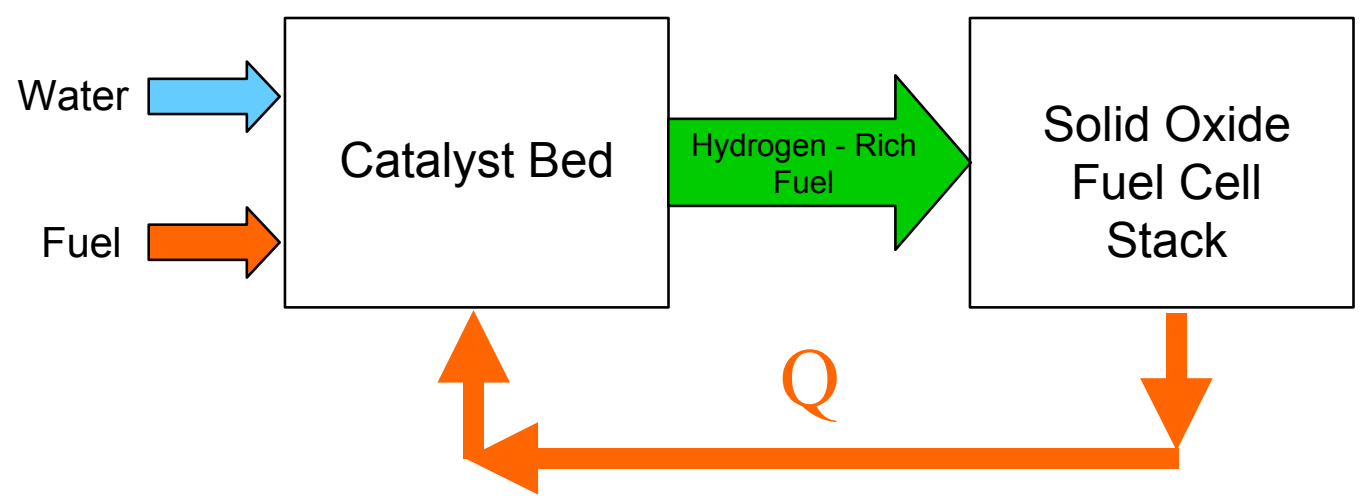

Figure 16. Schematic for an Efficient Steam Reformation Process. .

Thus, the goal of this effort is to improve overall SOFC system efficiency via the development of methods, designs, and materials to further enhance the oxidation of hydrocarbon fuels at the SOFC anode and/or internal reformation of fuels.

During this reporting period, planning activities were conducted for the internal reforming task. Technical brainstorming discussions were held to identify potential methods and techniques for internal reformation. These sessions led to the generation and documentation of sixteen ideas for carrying out reformation within the periphery of the stack.

These ideas will be subjected to a downselection process in which the most promising ideas are selected based upon ease of implementation and potential impact to system performance and efficiency. Following the downselection of the candidate ideas, experimental approaches and hardware will be designed and fabricated to evaluate feasibility.

\section{CONTROL AND SENSOR DEVELOPMENT}

\subsection{System Control Approach}

The form and functionality of the fuel cell control system will be highly influenced by the application requirements such as whether the system is load following and whether the system is tied to an external power grid. A flexible control structure will therefore be developed that can be modified and optimized for each system application (stationary, mobile, or military). 
The control system will provide the operator with the ability to automatically step through the startup sequence, regulate to commanded load demand points, step down through the normal shutdown sequence, perform basic health monitoring of the system, and handle emergency shutdown of the system. A dynamic model of the system is being developed using GE Hybrid Power Generation System's proprietary library of fuel cell system component models, and will be used to design and evaluate various control strategies prior to hardware implementation. The design of efficient controls for the fuel cell system requires consideration of many factors, significantly:

- With potentially wide load fluctuations, the controller should be able to maximize efficiency in different operational regions, and under different operating conditions. These include conditions that occur during startup, steady state operation and shutdown.

- The controller should be able to regulate power and voltage during steady state operation and maximize efficiency at setpoint.

- The controller should be able to minimize thermal stress and fatigue and limit component duty cycles that adversely affects the lifetime of the equipment.

Our baseline approach for the development of a control strategy will be using a combination of feedforward and feedback controls such as those implemented with the transportation PEM fuel cell system developed for DOE This control approach employs single loop proportional-integral-derivative (PID) type compensation for improved tracking and disturbance rejection, with a feedforward component that speeds up the system response and takes advantage of the a priori knowledge of system operation. Feedback state estimation is improved through the use of multiple measurement and sensor types where practical. Using this as a starting point, advanced control techniques will be investigated to determine an approach that best suits the performance requirements for the system.

In addition to the basic control functions, the controller will provide built-in test (BIT) and health monitoring around the system. The BIT will monitor sensors throughout the system and trigger alarms to shutdown the system if a sensor exceeds the specified operating range. Corrective and protective action will be programmed into the BIT to handle events.

\subsection{Control System Development}

A dynamic system model of the SECA conceptual system has been assembled and is currently being debugged and verified. The dynamic system model was assembled using GE Hybrid Power Generation Systems' proprietary Fuel Cell Dynamic Component Library. This model will be used to determine 
significant dynamic interactions within the system, perform various component and system level trade studies, and to develop the control system design. As the overall system design evolves and changes, the dynamic system model will be updated so that dynamic issues will be addressed throughout the system design and analysis process. This approach minimizes costs by reducing hardware tests and the risk of damaging hardware.

A rapid prototyping system (RPS) will be used as the control platform for hardware implementation of the controls developed through simulation. Using a RPS, the same controller used in simulation studies can be automatically coded and downloaded to the RPS for control of the hardware system. Control development cycle times are greatly reduced by using this approach and allow for alternative control designs to easily be implemented in hardware.

A fuel cell system, such as the one proposed, requires integrated control among several subsystems, including the fuel cell, power management subsystem, the fuel processor, and the fuel cell system balance of plant. Use of the RPS will provide for the flexibility of incorporating new control laws and using existing controllers for individual subsystems. Controllers in the fuel processor and power management subsystems can be easily interfaced to the RPS or their functionality can be assumed by the RPS. The RPS will serve as both the supervisory controller for the overall fuel cell system, which interacts with the individual subsystem controllers, and a lower level controller for the balance of plant.

The RPS controller will serve as the development platform for initial testing of the proposed fuel cell system. The RPS will then be used to generate requirements for a dedicated embedded controller that will minimize controller costs and maximize controller reliability. Depending on final system design and the particular requirements for each system application (stationary, mobile, or military) different embedded controllers may be needed to service each application.

Figure 17 shows the design for control process that is being used for controls system development on the SECA program. The controls task is currently in the Controls Requirements Definition process block. During this stage of the process system models are being developed, subsystem models are being developed and analyzed, the control loop analysis is being conducted to determine any dominant dynamic interactions in the system, and preliminary controls requirements are being formalized. The effort in the Q1 of 2002 has been primarily focused on building the dynamic system model and negotiating with other task teams on requirements for the system and various subsystems. 


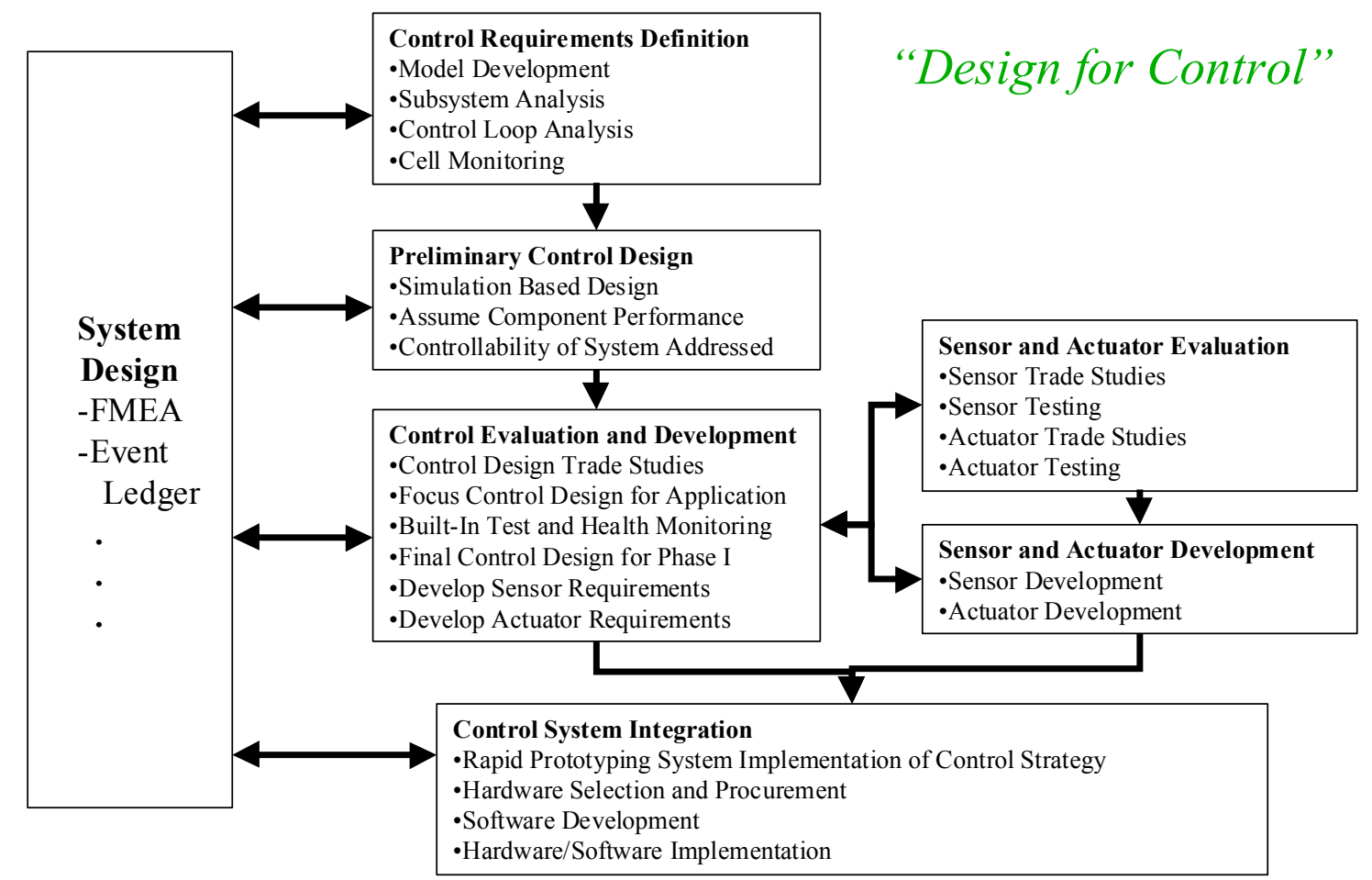

Figure 17. SECA Controls Design Process

\subsection{Sensor and Actuator Evaluation and Development}

The proposed fuel cell system will have temperatures as high as $1100^{\circ} \mathrm{C}$ in crucial portions of the system. To control the system it may therefore be necessary to use high temperature sensors and actuators in portions of the system. The control system design will seek to minimize the use of high temperature sensors and actuators to reduce cost and maximize the reliability of the system.

Sensor and actuator requirements will be generated using the dynamic system model once the preliminary control design is created. Sensors will be evaluated in terms of their dynamic response, accuracy, temperature requirements, and cost. Where the cost of a sensor is prohibitive for a production fuel cell system, the use of alternative sensors will be investigated as part of an indirect estimation technique to serve a similar function. A sensing strategy will be employed to create a cost effective, accurate, and fast responding set of sensors to indicate the state of the system to the controller.

Actuators will be evaluated in terms of their dynamic response and cost. This evaluation will seek to find low cost production grade valves that meet the temperature requirements for the different points in the fuel cell system. By considering controllability of the system from the initial stages of the system 
design, the requirements for the actuators in the system can be relaxed and the robustness of the system improved.

The preliminary sensor survey has shown that many off-the-shelf sensors exist that can be used directly or modified for use in the SECA system. The conclusion of this survey is that sensors should not be a high risk item for the control design, but further work will be needed in this area as the control design matures and cost targets for the control system are addressed. The preliminary actuator survey has shown that while there are many off-the-shelf valves that might fit the SECA conceptual design, further definition of the system is needed before the risk of finding high-temperature actuators can be quantified.

\section{THERMAL MANAGEMENT SUBSYSTEM}

In this reporting period, the focus of the thermal management task has been mainly on development of a novel recuperator design. This design should eliminate the need for a high-temperature heat exchanger, replacing it with a simple, low-cost solution.

An experiment will be setup to test the performance of the recuperation concept. In the experiment, the combustor will be simulated by producing hot gases in a combustion chamber.

\section{Conclusions}

Most of the work performed in this reporting period focused on defining requirements and baselining current capabilities, for the purpose of identifying and quantifying the key technology gaps which will need to be bridged in order to produce a successful SECA system. System-level requirements were initially defined, largely based on the DOE minimum requirements for Phase III. As work progresses, the Phase I requirements will be used, but for initial system design and analysis, it is important to focus on the ultimate goals of the program. It is undesirable to optimize a system design for SECA Phase I which will be incapable of reaching Phase III targets without wholesale changes.

Modeling and analysis of the baseline system were performed, leading to requirement definitions for the key subsystems, including the stack, fuel processor and thermal management. In parallel, a dynamic system model was developed, which will enable control and sensor design to be incorporated into the system from the beginning, which is critical for achieving a well-integrated, cost-effective system.

By comparing current stack performance and models to the stack requirements flowed down from the results of system analysis, the key technology gaps for the stack were identified. Cell performance and fuel utilization need significant improvement, which will be a major focus of the SECA program. Degradation rates, during steady-state operation and cycling, are 
unacceptably high, as supported by previous data; the key mechanisms are being explored and improved materials developed for improved stack lifetime.

In a similar fashion, gaps have been identified and approaches for improvement have been developed and are being explored in the areas of fuel processing and thermal management.

Overall, the groundwork has been laid for significant progress to be made over the next six months. Current capabilities have been established and baselined, the key technology gaps have been identified, and work has been planned to focus on eliminating these gaps and driving toward a successful SECA product.

\section{$\underline{\text { References }}$}

None. 